\title{
Rasayana Herbs of Ayurveda to Treat age Related Cognitive Decline: An Update
}

\author{
Reena Kulkarni ${ }^{*}$, Suhas Kumar Shetty², Rajarajeshwari N M³, Prasanna Narasimha Rao ${ }^{4}$ and Nayan J5 \\ 'Department of Kaumarabhritya, SDM College of Ayurveda, Tanniruhalla, Hassan-INDIA. \\ 2Department of Manasa Roga, SDM College of Ayurveda, Tanniruhalla, Hassan-INDIA. \\ ${ }^{3}$ Department of Samhita and Siddhanta, SDM College of Ayurveda, Tanniruhalla, Hassan-INDIA. \\ ${ }^{4}$ Department of Shalya Tantra, SDM College of Ayurveda, Tanniruhalla, Hassan-INDIA. \\ Department of Agada tantra, Sri Kalabairaveshvara Swamy Ayurveda Medical College, RPC layout, Vijayanagar, Bengaluru-40, Karnataka, INDIA.
}

\begin{abstract}
Introduction: Cognitive decline associated with aging could be minor or major neuro-cognitive disorder presenting with progressive intellectual deterioration interfering with day to day activities. Behaviour and personality changes may complicate the life in due course. Significant increase in global prevalence of people aged above 60 years has raised concerns on effective management of old age problems. Age related cognitive deficits and dementia raise to the level of epidemics and established management is yet underway. Principles of preventive health and rasayana (rejuvenative) herbs of Ayurveda are being extensively researched up on for their effectiveness in dementia. In this fourteen such herbs with anti dementia property are discussed with relevant research update. Methods: Herbs like amalaki (Emblica officinalis), hareetaki (Terminalia chebula), haridra (Curcuma longa), manduka parni (Centella asiatica), aindri (Bacopa monniera), yastimadhu (Glycirrhiza glabra), guduchi (Tinospora cordifolia), shankhapushpi (Convolvulus pleuricaulis), vacha (Acorus calamus), jyotishmati (Celastrus panniculata), kushmanda (Benincasa hispida), Jatamamsi (Nardostachys jatamamsi), ashvagandha (Withania somnifera) and kapikacchu (Mucuna pruriens (Linn.)) are already proven of their efficacy in experimental and preclinical levels. The contents and research evidences are collected from ayurveda database on medicinal plants used in Ayurveda and Siddha and other authentic literature, Google scholar, Science direct, online and print journals. Discussion: The herbs in discussion mostly act on reactive oxygen species and oxidative stress injury by antioxidant properties and neuro-
\end{abstract}

protective activity. Acetylcholine esterase inhibition, N-Methyl-D-Aspartate antagonism, Dopaminergic activity, Anti-amyloidogenic activity, Inhibition of Tau aggregation, neuroprotection and immune modulation are activity path ways. Tridosha namely Kapha, Pitta and Vata may be viewed to be categorically predominant in initial, middle and final stage of dementia. Selected herbs thus can be specific based on the pathology and relevant dosha predominance. Conclusion: Rasayana herbs with current updates and inferences can serve as an eye-opener for further researches at molecular and clinical aspect.

Key-words: Ayurveda, cognitive decline, Dementia, Herbs, Medhya, Rasayana.

Key Messages: Rasayana herbs of Ayurveda are a ray of hope to prevent and treat age related cognitive decline. Study on pharmacokinetics of rasayana herbs is the need of hour.

Corresponding author: Dr. Reena Kulkarni, Associate Professor, Department of Kaumarabhritya, SDM College of Ayurveda, Tanniruhalla, HassanINDIA.

Phone no: +919480478639

Email: drreenakulkarni@gmail.com

DOI : 10.5530/pj.2016.5.1

\section{INTRODUCTION}

Cognitive decline and dementia are emerging to be the greatest challenge to the mankind in recent years. The WHO 2012 Report "Dementia: a public health priority" estimates that there are at present 35.6 million people living in dementia worldwide. As the world's population ages, the frequency is expected to double by 2030 and triple by $2050 .^{2}$ Dementia is a disease of aging grouped under neuro-cognitive disorder presenting with progressive deterioration in multiple cognitive domains that is severe enough to interfere with daily functioning. ${ }^{3}$ The current estimate of 7.7 million new cases per year is an important benchmark, globally and regionally, particularly given the relatively low levels of heterogeneity between studies. ${ }^{1}$ Enormous researches in the field of medicine and new drug discovery have revolutionized management of old age problems. Unfortunately these developments have failed to impart substantial cure to dementia related issues. Some of the newer drugs and diet researched though documented significant results seem to be either too costly or cumbersome to adapt. Still these results are not translated into health indices. The total global societal costs of dementia were US\$ 604 billion in 2010 (Annex 6.11.5). ${ }^{1} 2030$ worldwide societal costs will have increased by $85 \% .{ }^{1}$ These facts have urged to look towards traditional health systems like Ayurveda (the Indian system of medicine) to reinvent the possibilities of healthy ageing and better quality of life for elderly. Ayurveda emphasises on healthy living through ahara (diet) and charya (regimen) based on dinacharya (daily requirement of the body) as well as to suit the ritu (seasonal variations). Periodical shodhana (cleansing), use of rasayana (rejuvenation) therapy go a long way in delaying the complications of ageing and deficits associated with it. Rasayana comprise of therapeutic procedures or preparation that on regular practice will boost nourishment, health, memory, intellect, immunity and hence longevity. Rasayana preparations include single herbs in various medicinal forms and poly herbal combinations specifically aimed to target general health and specific body tissues or attributes. Thus they could be ayushkameeya (to boost general health and longevity) rasayana,vayasthapana(anti-aging), medhya (nootropic or intellect boosters) rasayana, vyadhipratyaneeka (disease specific) rasayana. Rasayana herbs that aid to prevent age specific complications and boost cognitive faculty is the scope of this paper. Evidences used are mostly facts from researches on animal model or on bioactive principles with some of preclinical works on human system. The contents and cross references are collected from ayurveda database on Medicinal plants used in Ayurveda and Sidha and authentic literature, Google scholar, Science direct, online and print journals 


\section{Evidence based approach}

Amalaki (Emblica officinalis Gaertn.). Emblica is a medium to large deciduous tree. Dried fruit and fresh fruit, seed, leaves, root bark, flowers are used for medicinal purpose (Figure 1 ). ${ }^{4}$ Amalaki is highly regarded as vayasthapana and prescribed to be included in daily diet. ${ }^{5}$ It contains two hydrolysable tannins with low molecular weight (B1000), called emblicanin A (2,3-di-o-galloyl-4,6-(S)-hexahydroxydiphenoyl-2-keto-glucono-d-lactone) and emblicanin B (2,3,4,6-bis-(S)-hexahydroxydiphenoyl2- eto-glucono-d-lactone) along with other tannins like punigluconino (2,3-di-O-galloyl-4,6-(S)-hexahydroxydiphenoylgluconic acid) and pedunclagin (2,3,4,6-bis-(S)-hexahydroxydiphenoyl-D-glucose) exhibit strong antioxidant action. The two emblicanins $\mathrm{A}$ and $\mathrm{B}$ have been found to preserve erythrocytes against oxidative stress induced by asbestos, generator of superoxide radical. Fruit extract has been shown to have an anti-mutagenic activity in Ames test. ${ }^{6,7}$ Recently fruits have been tested for their antiviral activity, particularly for inhibiting reverse transcriptase in the replication of retroviruses like HIV-1. Fruit enhances the immune-defence ${ }^{8}$ and has a hypolipidemic ${ }^{9-11}$ and hepatoprotective activity. ${ }^{12}$ Dietary supplement of either of amalaki rasayana (a preparation from Indian goose berry) and rasa sindhoora (an organo-metallic ash prepared from mercury and sulphur) during larval period substantially suppressed neurodegeneration in fly models of polyQ and Alzheimer's disorders without any side effects. Dietary Amalaki Rasayana or Rasa Sindoor prevented accumulation of inclusion bodies and heat shock proteins, suppressed apoptosis, elevated the levels of heterogeneous nuclear ribonucleoproteins and cAMP response element binding protein and at the same time improved the ubiquitin proteasomal system for better protein clearance in affected cells. ${ }^{13}$

Hareetaki (Terminalia chebula Ketz.) is a large tree seen all over India. Fruits (myrobalans) are used in almost all the ailments (Figure 2). In 'Ayurveda', myrobalans are used in fevers, cough, asthma, urinary diseases, piles and worms. It is also useful in chronic diarrhea and dysentery, flatulence, vomiting, colic and enlarged spleen and liver. ${ }^{14}$ Phytochemical gallic acid, ellagic acid,tannic acid, ethyl gallate, chebulic acid, chebulagic acid, corilagin, mannitol, ascorbic acid (vitamin C), ${ }^{15}$ tannin, ${ }^{16}$ polyphenols, saponins, flavonoids and alkaloids. ${ }^{17}$ Chebulic myrobalans are extensively used in combination with belleric and embelic myrobalans under the name of 'Triphala' and also as adjuncts to other medicines in numerous diseases. ${ }^{18} 3 \mathrm{~g}$ of 'Haritaki' is used in the morning in empty stomach for body strengthening and anti-aging. ${ }^{19}$ Terminalia chebula showed maximum inhibition in the TBARS formation, restore antioxidant enzyme SOD from the radiation-induced damage..$^{20}$ Terminalia chebula exhibited antioxidant activity at different magnitudes of potency for anti-LPO, anti-superoxide radical formation and free radical scavenging activities. ${ }^{21}$ Intra peritoneal administration of ethanol extract of Terminalia chebula enhanced the learning and memory recall ability in male mice in an inverse dose-dependent manner. The pattern of changes of learning \& memory induced by TC extract was similar to those of donepezil, is a golden standard medicine for curing the AD..$^{22}$ Water, methanol, and 95\% ethanol extracts of the air-dried fruit of T. chebula Retzius demonstrated chemiluminescence antioxidant activities, and neuro-protective effects. The methanol and water extracts exhibit neuroprotective activities against $\mathrm{H}_{2} \mathrm{O}_{2}$-induced toxicity toward PC12 cells and are potential candidates for the treatment of $\mathrm{H}_{2} \mathrm{O}_{2}$ - induced neurodegenerative disease. ${ }^{23}$

Haridra (Curcuma longa linn), is a perennial herb regarded as master of Indian kitchen. Rhizome is widely used daily in food as well as medicine owing to its multi fold benefits (Figure 3). Rhizome piece or fine powder is added in culinary curry and used as a coloring agent in food. Biologically it is vishaghna (anti toxic), varnya (complexion promoter) and pramehaghna (anti diabetic). ${ }^{24}$ Traditional Indian medicine conside- red this polyphenolic compound as an effective therapy for several pathological conditions, ranging from asthma to epilepsy, from gall stone to diabetic wound healing. ${ }^{25}$ Ganguli and co-workers found Indians who regularly used cucrumin in curry in food reported lower prevalence of Alzheimer dementia. ${ }^{26}$ Yet another study reported that elderly healthy individuals who consumed it in curry showed better cognitive performance. ${ }^{27}$ Preclinical studies on curcumin reported anti-oxidant and neuro-protective activity of curcumin which was reported to be greater than tocopherol. In particular, curcumin protects neuron-like PC12 rat cells and umbilical endothelial cells against $\mathrm{A} \beta$ toxicity and reduces tau hyperphosphorylation ${ }^{28}$ promotes $\mathrm{A} \beta$ uptake from macrophages of $\mathrm{AD}$ patients ${ }^{29}$ and dose-dependently reduces fibril formation and extension, also destabilizing preformed $\mathrm{A} \beta$ fibrils ${ }^{30-32}$ Additionally, curcumin decreased levels of $\mathrm{A} \beta$-induced radical oxygen species ${ }^{33}$ and inhibits APP cleavage. ${ }^{34}$ Dietary curcumin $(2000 \mathrm{ppm})$ succeeded in reducing oxidative damage and increased microglial reaction near $\mathrm{A} \beta$ deposits. Additionally, low doses of curcumin (160 ppm) avoided the occurrence of spatial memory impairment in rat treated with $\mathrm{A} \beta$ infusion. In a study conducted in $\operatorname{Tg} 2576$ mice showed that curcumin reduced $\mathrm{A} \beta$ oligomer and fibril formation. ${ }^{32}$ Oral administration of a low dose of dietary curcumin (160 ppm) to an Alzheimer transgenic mouse model (Tg2576) for six months reported reduced inflammation and oxidative stress in the brain. ${ }^{35-37}$ Dietary curcumin $(2000 \mathrm{ppm})$ succeeded in reducing oxidative damage and increased microglial reaction near $\mathrm{A} \beta$ deposits. Additionally, low doses of curcumin (160 ppm) avoided the occurrence of spatial memory impairment in rat treated with $\mathrm{A} \beta$ infusion. Intravenous administration of curcumin $(7.7 \mathrm{mg} / \mathrm{kg} /$ day $)$ for 7 days demonstrated an enhanced clearance of $\mathrm{A} \beta$ deposit in mouse brain. ${ }^{38}$ Oral administration of curcumin in a range of 500 to $12000 \mathrm{mg}$ did not report any serious adverse events. curcumin nanoparticles were effective in Alzheimer Tg2576 transgenic mouse model. ${ }^{39}$ Similar increases in bioavailability were observed if curcumin-phospholipid complex or polymeric micellar curcumin were administered ${ }^{40-41}$ Oral administration of aqueous extracts of rhizome exhibited antidepressant activity in mice which was associated with inhibition of brain MAO type A..$^{42}$ Curcumin (10-80 mg/kg, i.p.) dose dependently inhibited the immobility period, increased serotonin (5hydroxytryptamine, 5HT) as well as dopamine levels (at higher doses), and inhibited the monoamine oxidase enzymes (both MAOA and MAOB higher doses) in mice. ${ }^{43}$ Human studies using curcumin inconclusive or deficient evidences in dementia which in large could be due to poor plasma concentration bioavailability of curcumin alone after oral administration. According to its pharmaco-dynamic properties, curcumin seems to act more as a neuro-protective agent than as a reversal medication. ${ }^{44}$ The neuro-protective activity is attributed to curcuminoids namely curcumin, demethoxycurcumin, and calabin-A. ${ }^{45,46}$ Majority of these results are reported to be from anti-oxidant and anti-inflammatory activity. ${ }^{47-51}$

Mandukaparni (Centella asiatica Linn.) is a prostrate, stoloniferous perennial herb rooting at nodes (Figure 4). ${ }^{52}$ Fresh whole plant juice is used for therapeutic purposes as Medhya (cognitive enhancer). ${ }^{53}$ Major constituents are saponin (medacoside, asiaticoside, medacassoside, asiatic acid, a new triterpenic acid. ${ }^{54}$ They act on behaviour besides being neuro-protective $e^{55}$ and brain growth promoter. ${ }^{56}$ Dendritic arborization is supposed to be the neuronal basis for improved learning and memory. ${ }^{57}$ Anti-seizure activity may result from direct or indirect modulation of ATPase activity ${ }^{58}$ Centella asiatica inhibits the memory impairment induced by scopolamine through the inhibition of AChE. ${ }^{59}$ BR-16A (Mentat), a formulation containing Centella asiatica proved for its antistress effects. ${ }^{60}$ Methanol extract of Centella asiatica showed highest free radical scavenging activity that can be attributed to the presence of polyphenols and flavonoids as this fraction contains maximum amount of these secondary metabolites $(0.07 \mathrm{mg} / \mathrm{ml})$. It also exhibited DNA 
damage protection activity on pRSETA plasmid DNA in TE buffer (10 mM Tris-Cl and $1 \mathrm{mM}$ EDTA) pH 8.0. Chloroform extract of Centella showed highest poly phenolic activity followed by methanol extracts (9.04 $\mu \mathrm{g} / \mathrm{mg}, 7.7 \mu \mathrm{g} / \mathrm{mg}, 6.76 \mu \mathrm{g} / \mathrm{mg}$ Gallic acid equivalents respectively); while flavonoids were abundant in water extracts, followed by chloroform extracts. These two namely poly phenols and flavonoids are responsible for potent anti-oxidant and terminate free radicals. ${ }^{61}$ Rats treated with C. asiatica in another study showed a dose dependent increase in both cognitive and behaviour paradigms. A significant decrease in MDA and an increase in glutathione and catalase levels were observed only in rats treated with 200 and $300 \mathrm{mg} / \mathrm{kg}$ C. asiatica. The results indicated that an aqueous extract of $C$. asiatica is effective in preventing the cognitive deficits, as well as oxidative stress, caused by i.c.v. STZ in rats. ${ }^{62}$ The rat pups (7-days-old) were fed with 2, 4 and $6 \mathrm{ml} / \mathrm{kg}$ body of fresh leaf juice of CeA for 2, 4 and 6 weeks showed significant increase in dendritic length (intersections) and dendritic branching points along the length of dendrites of the amygdaloid neurons of rats treated with 4 and $6 \mathrm{ml} / \mathrm{kg}$ body weight/day of CeA for longer periods of time (i.e. 4 and 6 weeks). The study indicated that constituents/active principles present in CeA fresh leaf juice has neuronal dendritic growth stimulating property; hence it can be used for enhancing neuronal dendrites in stress and other neurodegenerative and memory disorders. ${ }^{63}$ Total triterpenes from Centella asiatica exhibhited anti-depressant activity in mice on forced swimming test. ${ }^{64}$ Administration of Centella asiatica at $1,000 \mathrm{mg} / \mathrm{kg}$ b.wt for a period of 30 days in albino rats, showed organ specific toxicity. ${ }^{65}$

Aindri (Bacopa monniera) commonly called as brahmi belongs to Scrophulariaceae family. ${ }^{66}$ It is a small, creeping marshy herb grown throughout India (Figure 5). ${ }^{67}$ Most beneficial therapeutic form is macerated whole plant juice. Properties are said to be similar to that of Mandukaparni. ${ }^{68}$ Bacopa monniera is a well-known nootropic plant reported for its tranquilizing, ${ }^{69}$ sedative action, ${ }^{70}$ cognitive enhancer, ${ }^{71}$ hepato-protective, ${ }^{72}$ memory enhancer ${ }^{73}$ and antioxidant actions. ${ }^{74-76}$ Neuro-protective activity may be ascribed to having its reactive oxygen species scavenging property. ${ }^{77}$ Bacopa monniera is a saponin rich plant. ${ }^{78}$ Bacosides are the main active nootropic principle present in the alcoholic extract of the plant. $^{79}$

Isolation of a new saponin, a jujubogenin, named bacopasaponin G, and a new glycoside, phenylethyl alcohol was reported. ${ }^{80}$ Three new saponins designated as bacopasides III, IV and V isolated. ${ }^{81}$ Apart from memory enhancer activity these bacosides have the potential to modulate the activities of heat stock protein (Hsp70) expression, cytochrome P450 and superoxide dismutase in the rat brain. ${ }^{82}$ On rats, alcoholic extract increases both cognitive function and retention capacity, decreases retrograde amnesia and protects from phenytoin -induced cognitive deficit. ${ }^{83}$ It is mainly utilized in the treatment of memory and attention disorders. ${ }^{84}$ Recent studies have indicated antioxidant effect of bacosides (triternoid saponin isolated from Bacopa monniera) against chronic toxin induced oxidative damage in rat brain ${ }^{85}$ and thyroid $\mathrm{T}_{4}$ hormone stimulating activity in animals in high doses. ${ }^{86}$

Organic extract of Bacopa monniera in effective doses continuously for six months revealed beneficial effect in improving memory attention span and behavioural problems among demented elderly people. ${ }^{87}$ Bacopa monniera extract was able to reverse both anterograde and retrograde amnesia in mice with scopolamine induced amnesia. Thus it was concluded that B. monniera effects on cholinergic system may be helpful for developing alternative therapeutic approaches for the treatment of Alzheimer's disease ${ }^{88} \mathrm{~A}$ study evaluated the effect of orally administered alcoholic extracts of Bacopa monniera (at doses of 20, 40 and $80 \mathrm{mg} / \mathrm{kg}$ ) on cognitive function and neuro-degeneration in animal models of Alzheimer's disease induced by ethylcholine aziridinium ion (AF64A). Bacopa monniera extract improved the escape latency time $(\mathrm{p}<0.01)$ in
Morris water maze test. Moreover, the reduction of neurons and cholinergic neuron densities were also mitigated. The study suggests that Bacopa monniera is a potential cognitive enhancer and neuro-protectant against Alzheimer's disease. ${ }^{89}$ Yet another study in experimental rats with oral administration of $\mathrm{AlCl}_{3}$ and Bacopa monniera extract $50 \mathrm{mg} / \mathrm{kg} /$ day in drinking water for 1 month prevented accumulation of lipid and protein damage significantly induced by aluminium intake. Activity was similar to that of 1-deprenyl. It also inhibited decline in the activity of endogenous antioxidant enzymes associated with aluminium administration. Results suggest that $B$. monniera has potential to protect brain from oxidative damage resulting from aluminium toxicity. ${ }^{90}$ B. monniera (50 $\mathrm{mg} / \mathrm{kg}$ body weight) supplementation reversed memory impairment in the colchicine treated rats by attenuating oxidative damage, as evident by decreased LPO and protein carbonyl levels and restoration in activities of the antioxidant enzymes. Also, Bacopa monnieri supplementation was able to restore the altered activity of membrane bound enzymes $\left(\mathrm{Na}^{+} \mathrm{K}^{+}\right.$ATPase and AChE) as compared to the controls. ${ }^{90}$ In adult swiss mice extracts of Bacopa monnieri produced anti-dementic activity against scopolamine induced dementia and a dose dependent antiAChE activity. ${ }^{91,92}$ special BM extract (CDRI-08) ameliorated amnesic effect of scopolamine by decreasing acetyl cholinesterase activity and drastically up regulating the mRNA and protein expression of BDNF, Arc, and GFAP in mouse cerebrum. Study also provides first molecular evidence for anti-amnesic potential of CDRI-08 via enhancement of CREB mediated basal transcriptional machinery of memory linked both neuronal and glial plasticity markers. ${ }^{93}$

In a randomized, double-blind, placebo-controlled clinical trial on elderly participants aged 65 or older (mean 73.5 years) without clinical signs of dementia, B. monniera extract (300 $\mathrm{mg} /$ day per oral) enhanced Rey Auditory Verbal Learning Test(AVLT) delayed word recall memory scores and Stroop Task assessing the ability to ignore irrelevant information. Study also showed reduction in Center for Epidemiologic Studies Depression scale (CESD-10) depression scores, combined state plus trait anxiety scores, and heart rate over time. ${ }^{94}$ In an open label, prospective, uncontrolled, nonrandomized study on human participants newly diagnosed Alzheimer's disease, Bacopa monnieri standardized extract $300 \mathrm{mg}$ twice a day orally for 6 months resulted in improvement in orientation (of time, place \& person), attention and in language components (reading, writing \& comprehension) of cognitive functions using Mini Mental State Examination Scale (MMSES). The trial also reported improvement in their quality of life, and decrease in the irritability and insomnia. ${ }^{95}$

Yastimadhu (Glycirrhiza glabra Linn.) is a hardy herb or under shrub belonging to Fabaceae family. ${ }^{96}$ Fine powder of dried root is used internally with milk for therapeutic purpose as Medhya (Figure 6). Active ingredients are glycyrrhizine, flavonones, ${ }^{97}$ is oflavones, glycyrrhetenic acid, ${ }^{98}$ six phenolic compounds.$^{99}$ Multidimensional activities of Yashtimadhu may be attributed to glycyrrhizine and flavonones. Yashtimadhu is cytotoxic and its prolonged use may lead to pseudoaldosteronism, ${ }^{100}$ hyperkalemia, ${ }^{101}$ and hypertension. ${ }^{102,103}$ The roots and rhizomes of G. glabra has been studied with respect to spatial learning and passive avoidance ${ }^{104}$ preliminary free radical scavenging ${ }^{105}$ cerebral is chemia ${ }^{106}$ and antioxidant capacity towards LDL oxidation. ${ }^{107}$ Glycyrrhiza glabra aqueous extract markedly improves antihypoxic effects induced by sodium nitrite in rats and this effect may be mediated by its antioxidant properties. ${ }^{108,109}$ The roots and rhizomes of Glycyrrhiza glabra is an efficient brain tonic; it increases the circulation into the CNS system and balance the sugar levels in the blood. ${ }^{110}$ Liquorice has significant action on memory enhancing activity in dementia. ${ }^{111}$ It significantly improved learning and memory on scopolamine induced dementia. Oral glabridin administration (25 and $50 \mathrm{mg} / \mathrm{kg}$ ) improved learning and memory in 


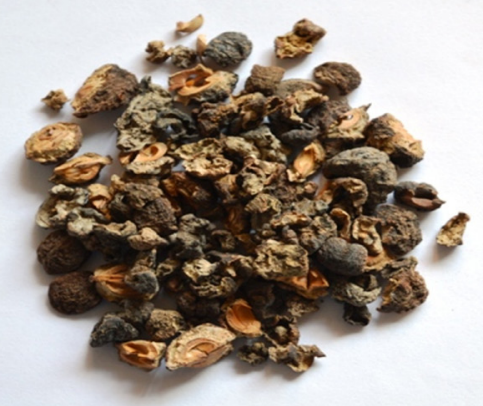

Figure 1: Amalaki (Emblica officinalis) fruit (dried).

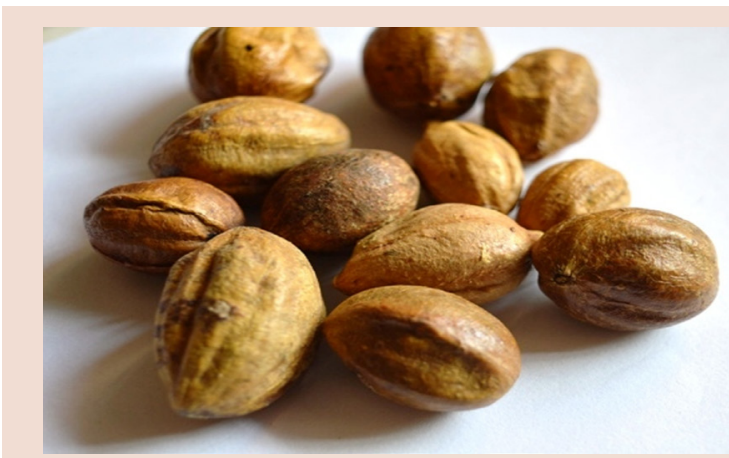

Figure 2: Hareetaki (Terminalia chebula).

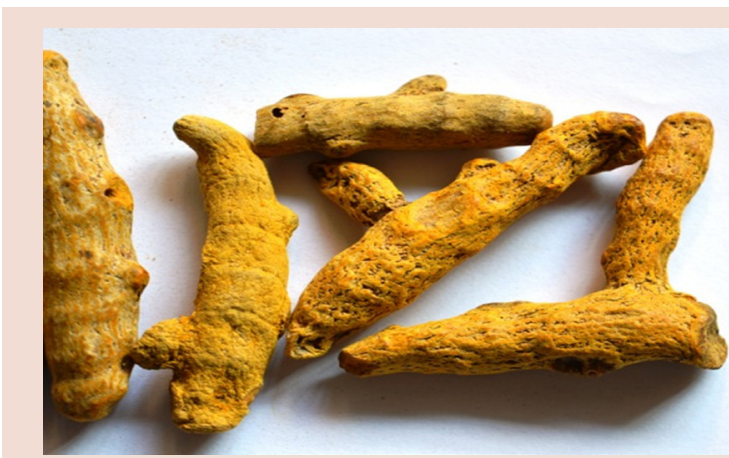

Figure 3: Haridra (Curcuma longa linn).

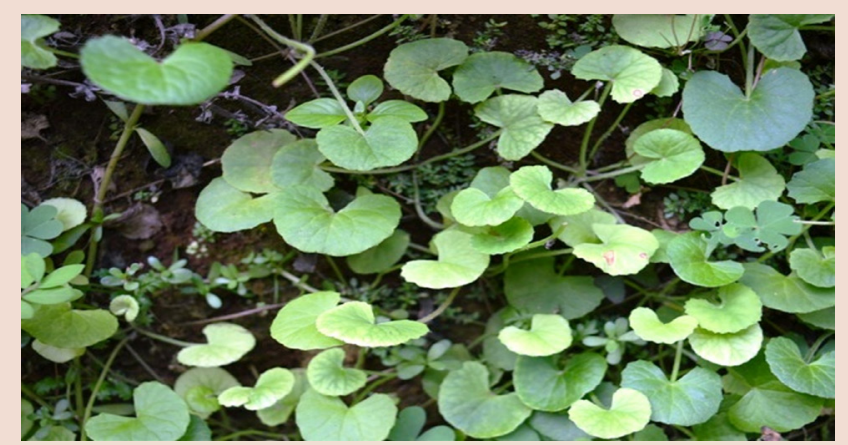

Figure 4: Mandukaparni (Centella asiatica Linn.).

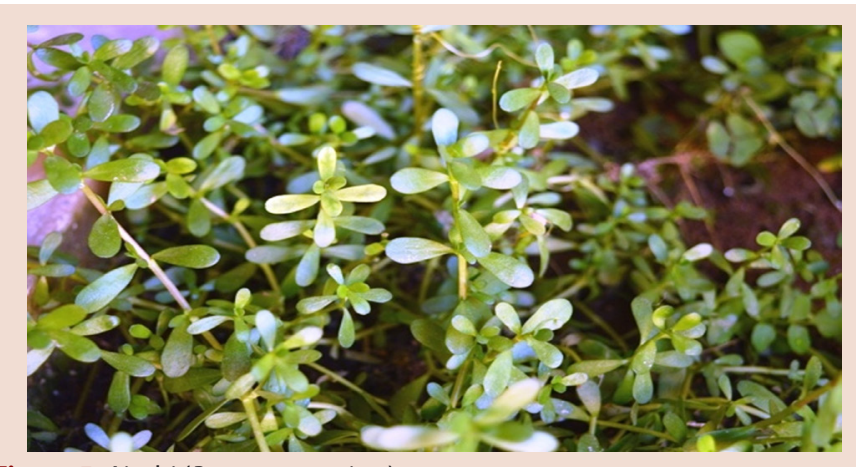

Figure 5: Aindri (Bacopa monniera).

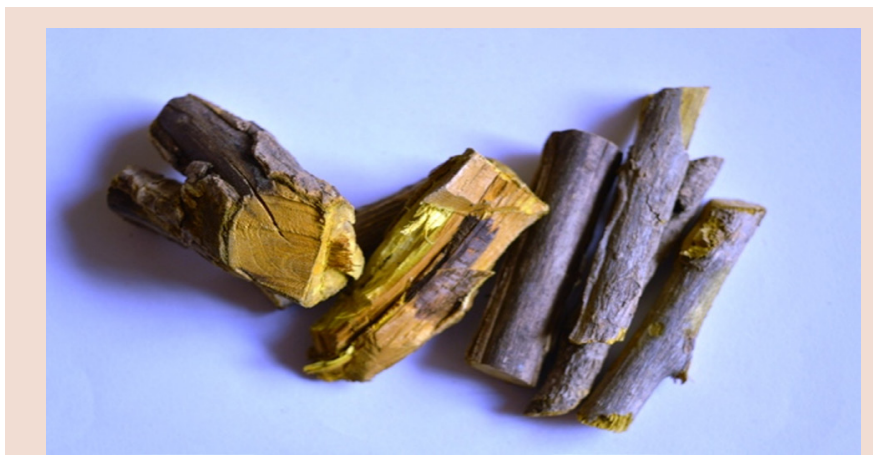

Figure 6: Yastimadhu (Glycirrhiza glabra Linn.).

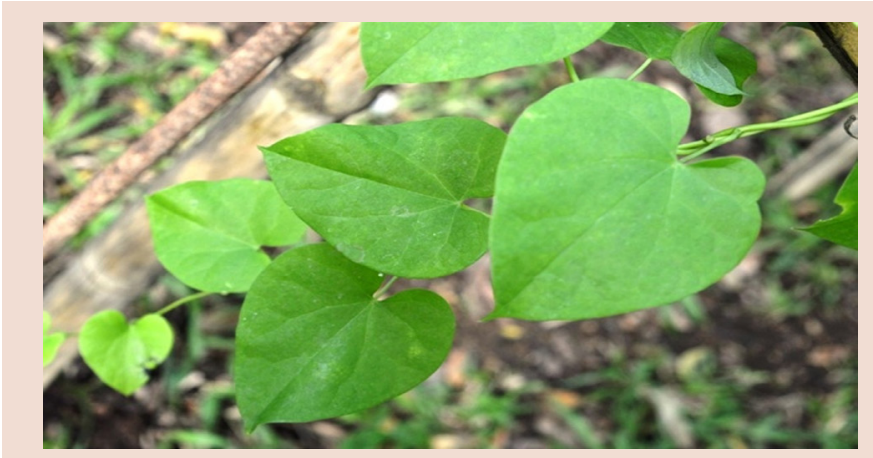

Figure 7: Guduchi (Tinospora cordifolia).

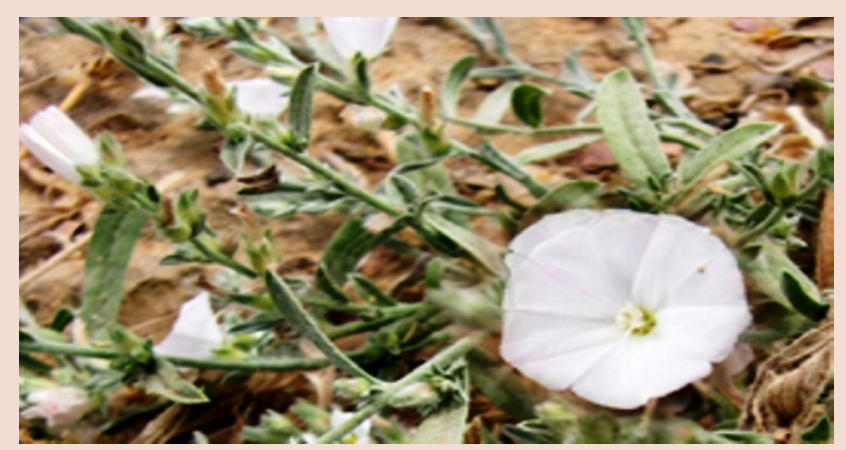

Figure 8: Shankhapushpi (Convolvulus pleuricaulis). 


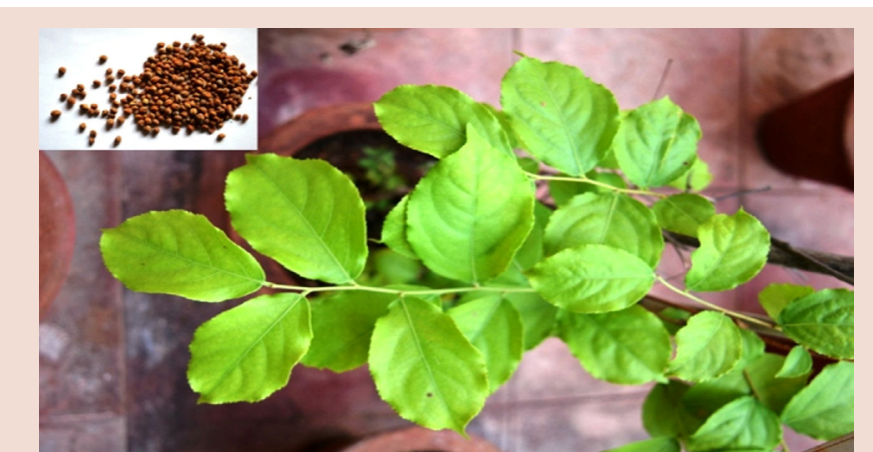

Figure 9: Jyotishmati (Celastrus panniculata).

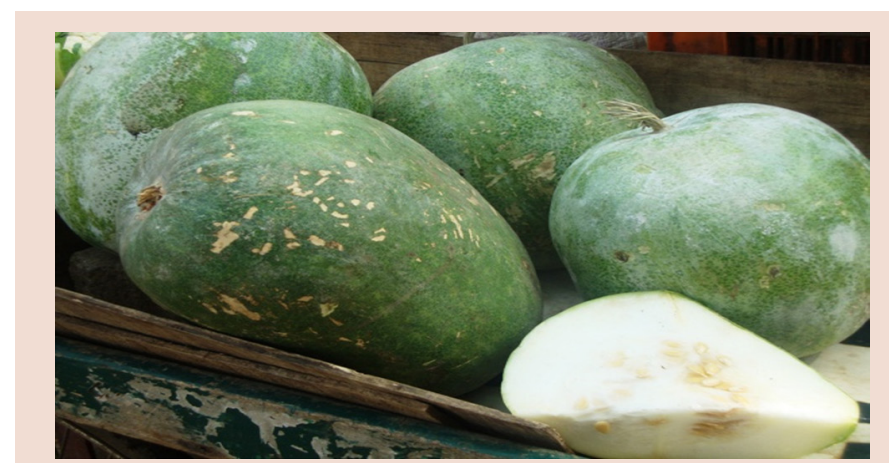

Figure 10: Kushmanda (Benincasa hispida).
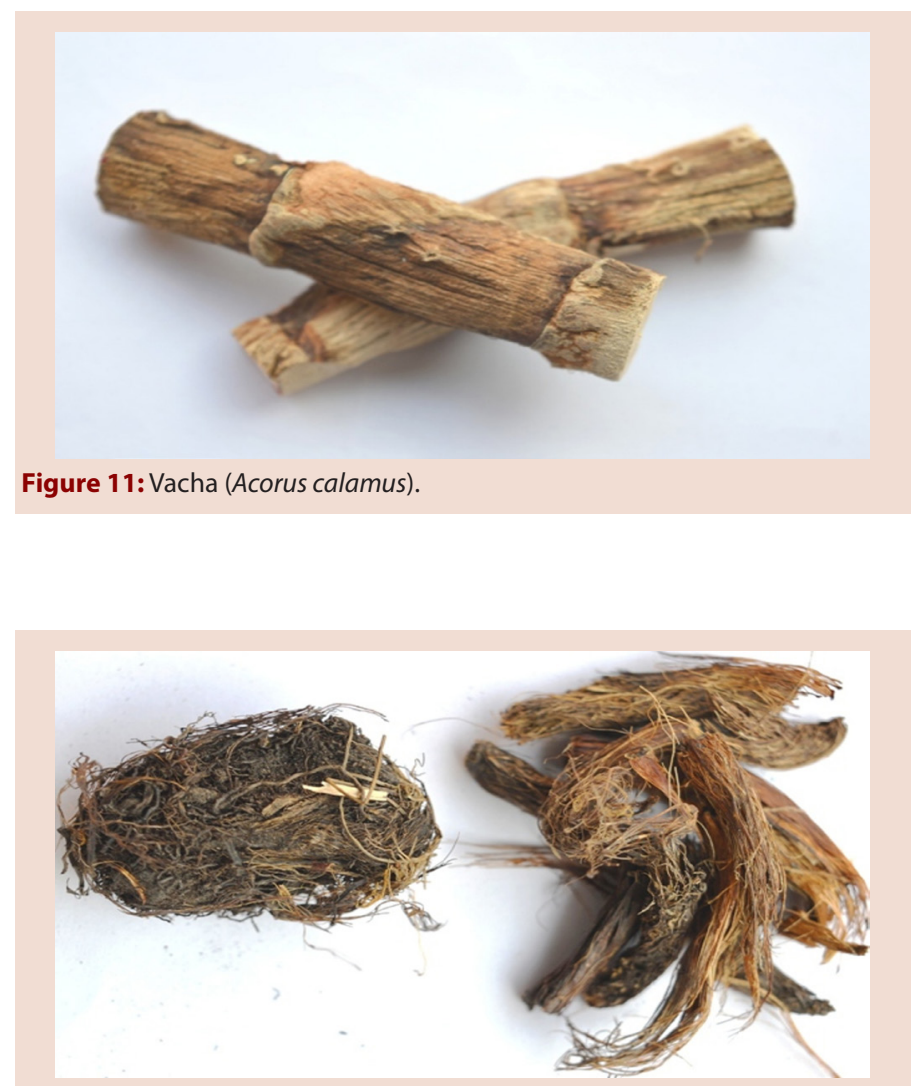

Figure 12: Jatamamsi (Nardostachys jatamamsi).

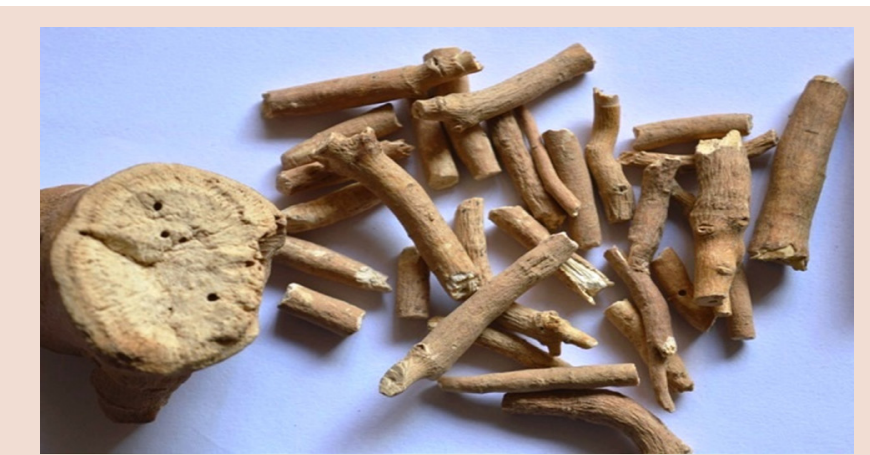

Figure 13: Ashvagandha (Withania somnifera).

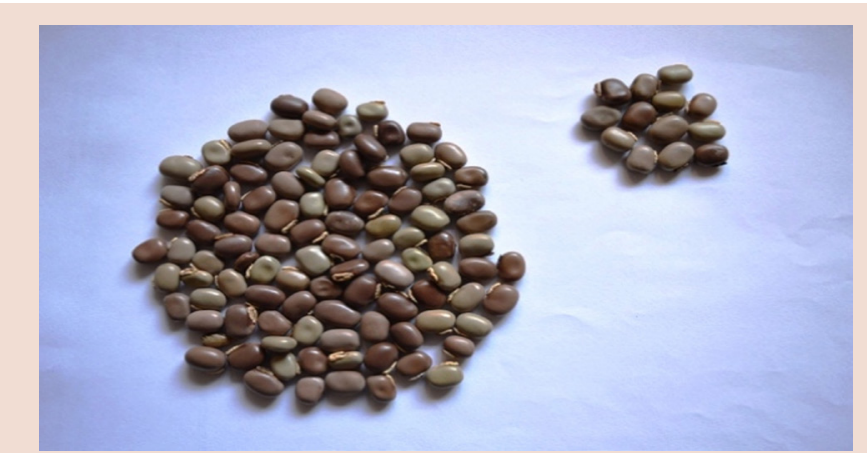

Figure 14: Kapikacchu (Mucuna pruriens (Linn.).

non-diabetic rats, it also reversed learning and memory deficits of diabetic rats. The study concluded that glabridin prevented the deleterious effects of diabetes on learning and memory in rats by combination of antioxidant, neuroprotective and anticholinesterase properties. ${ }^{112}$ The higher doses ( 2 and $4 \mathrm{mg} / \mathrm{kg}$; p.o.) of glabridin and piracetam significantly antagonized the amnesia induced by scopolamine $(0.5 \mathrm{mg} / \mathrm{kg}$; i.p.) in an experimental model. Furthermore, both glabridin $(2$ and $4 \mathrm{mg} / \mathrm{kg}$; p.o.) and metrifonate (50 mg/kg; i.p.), used as a standard drug, remarkably reduced the brain cholinesterase activity in mice compared to the control group. The study indicated that glabridin can be a promising candidate for memory improvement and can be used in the management of Alzheimer patients. ${ }^{113}$

Guduchi (Tinospora cordifolia (Wild) Miers) is a large glabrous, deciduous, climbing shrub of Menispermaceae family found throughout tropical India (Figure 7). ${ }^{114}$ Juice of whole plant is used therapeutically as Medhya. ${ }^{53}$ It is also used in the form of decoction, powder and Satwa (starch extract of stem). Its root is known for its anti-stress, anti-leprotic and anti-malarial activities. ${ }^{115,116}$ Chemical constituents' classes are alkaloids, diterpenoid lactones, glycosides, steroids, sesquiterpenoid, phenolics, aliphatic compounds and polysaccharides. ${ }^{117}$ Neuroprotective and ameliorative properties are due to their antioxidant and trace element contents. ${ }^{118}$ Tinospora cordifolia is known to be a rich source of trace elements (Zinc and Copper) which act as antioxidants and protects cells from the damaging effects of oxygen radicals generated during immune activation. ${ }^{119}$ It increases the blood profile and has lead scavenging activity. ${ }^{120}$ Tinospora cordifolia has been claimed to possess learning and memory enhancing, ${ }^{121}$ antioxidant, ${ }^{122,123}$ and anti-stress activity. ${ }^{124}$ Tinospora cordifolia enhanced the cognition in normal and cognition deficits animals in behavioural test Hebb William maze and the passive avoidance 
Kulkarni et al.: Rasayana herbs to treat age related cognitive decline

task. ${ }^{125}$ Mechanism of cognitive enhancement is by immune-stimulation and increasing the synthesis of acetylcholine, this supplementation of choline enhances the cognition. ${ }^{126}$ Myriad actions of Guduchi may be attributed to its antioxidant ${ }^{127,128}$ and immune-modulatory properties. ${ }^{129}$ Administration of aqueous and alcoholic extracts of Tc (100 and $200 \mathrm{mg} / \mathrm{kg}$ respectively) for 15 days in an experimental model enhanced cognition (learning and memory) in normal rats and rats with cyclosporine induced memory deficit. It also provided hippocampal protection in normal rats as against cyclosporine treated rats showed neurodegenerative changes on histopathological study. ${ }^{130}$ Oral administration of Tinospora cordifolia (500 mg aqueous extract) for 30 healthy volunteers (age 18-30 years) in a double blind, randomized and placebo controlled design enhanced verbal learning and memory and logical memory (of immediate and short term type). ${ }^{131}$ Tc also showed significant antidepressant activity by increasing brain monoamines. ${ }^{132}$ The most likely antidepressant mechanisms involve inhibiting reuptake of mines in the brain, improved levels of norepinephrine (NE), serotonin (5hydroxytryptamine or 5HT), and dopamine (DA), and decreased levels of gammaaminobutyric acid (GABA). ${ }^{133}$

Shankhapushpi (Convolvulus pleuricaulis Chois) is a perennial, prostate or sub erect spreading hairy herb (Figure 8), ${ }^{134}$ found throughout India. ${ }^{135}$ Recommended therapeutic form is fine paste of whole plant. Highly regarded as Medhya (intellect promoter).$^{53}$ Important chemical principles are microphyllic acid, shankhapushpin, kaempferol-kaempferol-3-glucoside, 3, 4 dihydroxycinnamic acid, sitosterols. Neuro-protective and intellect promoting activity implicated to free radical scavenging and antioxidant property. ${ }^{136}$ BR-16A (Mentat), a poly herbal combination containing Shankhapushpi significantly reversed the social isolation stress-induced prolongation of onset and decrease in pentobarbitone-induced sleep, increased total motor activity and stress-induced antinociception in experimental model. ${ }^{137}$ Ayushman-8 (containing Shankhpushpi, Brahmi and Vacha) reported to be effective on Manasa-mandata (mental retardation). ${ }^{138}$ Shankhapushpi compound containing Shankhapushpi, Sarpagandha, and Gokshura in equal quanitities studied to be effective in Chittodvega (anxiety disorders). ${ }^{139}$ Sanjay Parsania ${ }^{140}$ reported Shankhapushpi to be effective in relieving signs and symptoms of Chittodvega (anxiety disorders). Herbalists believe that Shankhpushpi calms the nerves by regulating the body's production of the stress hormones, adrenaline and cortisol. ${ }^{141} \mathrm{Few}$ investigations reports that Shankhpushpi has potent depressive action in mice. ${ }^{142}$

In an experimental study, a dose dependent enhancement of memory was observed with Convolvulus pluricaulis and Asparagus racemosus. Hippocampal regions associated with the learning and memory functions showed dose dependent increase in AChE activity in CA1 with AS and $\mathrm{CA} 3$ area with $\mathrm{CP}$ treatment. The underlying mechanism of these actions of $\mathrm{CP}$ and $\mathrm{AE}$ may be attributed to their antioxidant, neuro-protective and cholinergic properties. ${ }^{143}$ Daily administration of CP $(150 \mathrm{mg} / \mathrm{kg})$ for 3 months along with aluminium chloride $(50 \mathrm{mg} / \mathrm{kg}$ ) decreased the elevated enzymatic activity of acetylcholine esterase and also inhibited the decline in $\mathrm{Na}^{+} / \mathrm{K}^{+}$ATPase activity aluminium intake. Beside, preventing accumulation of lipid and protein damage, changes in the levels of endogenous antioxidant enzymes associated with aluminium administration were also improved. Oral administration of CP preserved the mRNA levels of muscarinic receptor 1 (M1 receptor), choline acetyl transferase (ChAT) and Nerve Growth Factor- Tyrosine kinase A receptor (NGF-TrkA). It also ameliorated the up regulated protein expression of cyclin dependent kinase5 (Cdk5) induced by aluminium. The potential of CPE to inhibit aluminium induced toxicity was compared with rivastigmine tartrate $(1 \mathrm{mg} / \mathrm{kg})$, which was taken as standard. The potential of the extract to prevent aluminium-induced neurotoxicity was also reflected at the microscopic level, which indicated its neuro-protective effects. ${ }^{144}$
Oral administration of $\mathrm{CP}$ extract $(150 \mathrm{mg} / \mathrm{kg})$ to scopolamine treated rats reduced the increased protein and mRNA levels of tau and $A \beta P P$ levels followed by reduction in $A \beta$ levels compared with scopolamine treated group. ${ }^{145}$

Jyotishmati (Celastrus panniculata) is a large, woody, climbing shrub with ovate or obvovate leaves found all over India (Figure 9). ${ }^{146}$ Seed oil (Jyotishmati Taila) is known for Medhya action. ${ }^{147}$ This oil contains several terpenoids like paniculatadiol, b-sitosterol, celastrol, b-amyrin, pristimerin, but its most investigated components are its many sesquiterpenoids, dihydroagarofuran-type polyols or esters. ${ }^{148}$ Celastrus paniculata showed antioxidant activity by decreasing the lipid peroxidation ${ }^{149}$ and anti-arthritic activity in rat model. ${ }^{150}$ Seed oil of Celastrus panniculata (Malkangni) reversed scopolamine-induced deficits in navigational memory task in young adult rats. ${ }^{151}$ study revealed an increased cholinergic activity of brain is noted resultant up on decreased in AChE activity assayed from hypothalamus, frontal cortex and hippocampus of the rat brain treated with $400 \mathrm{mg} / \mathrm{kg}$ body weight. No side effects were observed with administration of the seed oil. ${ }^{152}$

Kushmanda (Benincasa hispida) belonging to Cucurbitaceae an extensive trailing or climbing herb cultivated throughout the plains of India as a vegetable. ${ }^{153}$ The fruit, broadly cylindrical, is covered with a waxy bloom (Figure 10). ${ }^{154}$ Phytochemical analysis of Benincasa hispida shows presence of alkaloids, flavinoids, saponins and steroids. ${ }^{155}$ Benincasa cerifera serves as ROS scavenger and an antioxidant effective agent. ${ }^{156}$ It has a tissue protective preventive effect on colchicine induced Alzheimer's disease via direct and indirect antioxidant activity. ${ }^{157}$

Vacha (Acorus calamus) of Araceae family is a semiaquatic, perennial, aromatic herb with its rhizome being horizontal, rounded, somewhat vertically compressed, spongy and leaves grass like and sword shaped; grown all over India. ${ }^{158}$ Rhizome is useful part having Medhya quality (Figure 11). It has been used in Indian and Chinese system of medicine for hundreds of years to cure diseases especially the central nervous system (CNS) abnormalities. ${ }^{159-162}$ Active chemical principles are $\alpha$-asarone, elemicine, cis-isoelemicine, cis and trans isoeugenol and their methyl ethers, camphene, P-cymene, bgurjunene, a-selinene, b-cadinene, camphor,terpinen-4-ol, aterpineol and a-calacorene, acorone, acrenone, acoragermacrone, 2-deca-4,7 dienol, shyobunones, linalool and preisocalamendiol. Acoradin, galangin, 2, 4, 5- trimethoxy benzaldehyde, 2,5- dimethoxybenzoquinone, calamendiol,spathulenol and sitosterol are also present. ${ }^{163,164}$ It has been proved for its analgesic and anticonvulsant, ${ }^{165}$ hepatoprotective, ${ }^{166}$ antioxidant, ${ }^{167,168}$ antimutagenic, ${ }^{169}$ sedative and hypothermic effects ${ }^{170}$ good in clearing speech to the children ${ }^{171,172}$ and useful in schizophrenic psychosis. ${ }^{173}$ Acorus calamus possesses a beneficial memory enhancing property for memory impairment, learning performance, and behavior modification. Essential oil from rhizome and $\beta$-asarone inhibits the acetylcholinesterase (AChE). ${ }^{174,175} \alpha$-asarone inhibits the activity of hippocampal neurons and produces antiepileptic effect in central nervous system through enhancing tonic GABAergic inhibition. ${ }^{176}$ Food and Drug Administration banned usage its oil in food formulations and in other therapeutic preparations $^{177}$ due carcinogenic and toxic properties of $\beta$-asarone compound. ${ }^{178}$ Ethanolic extract demonstrated to possess potential antioxidative, anti-inflammatory as well as neuroprotective actions. ${ }^{179-181}$ Experimentally, it has also been reported to decrease free radical generation via enhancement of anti-oxidant mechanisms such as increase in superoxide dismutase, catalase, reduced glutathione and glutathione peroxidise levels. ${ }^{182}$ Additionally, it is shown to be a neuroprotective action against the hypoxic (ischemia) event and chemical (i.e. acrylamide) induced severe insult in nervous system. ${ }^{183-185}$ Acorus calamus has also been shown to modulate calcium channel activity ${ }^{186}$ thus attenuating CCI induced peripheral neuropathic pain. ${ }^{187}$ Oral administration of 
methanol extract of rhizome of A. calamus in rodents exhibited an antidepressant-like activity, probably by modulating the central neurochemical as well as HPA axis in response to stress induced by FST. ${ }^{188}$

Jatamamsi (Nardostachys jatamamsi) is an erect perennial aromatic herb with long, stout, woody, greyish, rhizomatous, tail-like rootstock covered with reddish-brown hairs or tufted fibrous remains of the petioles of withered radical leaves, ${ }^{189}$ and belongs to Valerianaceae family. Rhizome is used for medicinal purposes as it is Bhutaghna or Manasa Doshahara (relieves of psychiatric problems) and Medhya (Figure 12). ${ }^{190}$ Roots and rhizomes of $N$. jatamansi are used to treat hysteria, epilepsy, and convulsions. ${ }^{191}$ The decoction of the drug is also used in neurological disorders, insomnia and disorders of cardiovascular system. ${ }^{192}$ Rhizomes contain a terpenoid ester, nardostachysin $\mathrm{I}^{193}$ and variety of sesquiterpenes and coumarins.It is proven to improve learning and memory in mice ${ }^{194}$ and also to enhance biogenic amine activity. ${ }^{195}$ An alcoholic extract of this plant administered to both young and aged mice significantly improved learning and memory and also reversed aging induced amnesia due to diazepam and scopolamine. ${ }^{196}$ Nardostachys jatamansi extract prevented chronic restraint stress-induced learning and memory deficits in a radial arm maze task. ${ }^{197}$ In another study, hydroalcohol extract of Nardostachys jatamansi rhizome showed AChE inhibitory activity with an $\mathrm{IC}_{50}$ value of $130.11612 \mathrm{mg} / \mathrm{ml} .{ }^{198,199}$ An acetone extract of $N$. jatamansi has shown significant inhibition of benzoyl peroxide-induced cutaneous oxidative stress, toxicity, and ear oedema in mice. ${ }^{200}$ Ethanolic extracts of NJ showed a dose dependent increase in the number of surviving neurons and anti-Parkinson effects. ${ }^{201}$

Ashvagandha (Withania somnifera) commonly known as Indian winter cherry or Indian ginseng is most used rasayana herb in Indian system of medicine. It is clinically used for the treatment of general debility, consumption, nervous exhaustion, insomnia, loss of memory, and so on. ${ }^{202}$ finely powdered root is therapeutically used with water, milk, ghee (clarified butter) or honey. Root is extensively used for therapeutic purpose (Figure 13). Chemical constituents include alkaloids (isopelletierine, anaferine, cuseohygrine, anahygrine, etc.), steroidal lactones (withanolides, withaferins) and saponins. ${ }^{203}$ Withania has been reported as promising anti-cancer drug candidate due to its cytotoxic, ${ }^{204}$ apoptotic, ${ }^{205}$ antimetastatic $^{206}$ anti-mitotic ${ }^{207}$ and anti-angiogenesis properties. ${ }^{208}$ The herb is reported to possess beneficial effects in a wide range of central nervous system (CNS) pathology in rodents. These include catalepsy, cognitive and memory impairment, orofacial dyskinesia, ${ }^{10}$ stress, Parkinson's disease (PD), Huntington's disease (HD), Alzheimer's disease (AD), cerebral stroke, epilepsy, excitotoxicity, in sleep disturbed mice, chronic fatigue syndrome, streptozotocin induced oxidative stress, copper-induced oxidative stress and rotenone-induced oxidative stress. ${ }^{209}$ Withaferin A was reported dose dependent anti-cancer $(3.5 \mathrm{mg} / \mathrm{kg})$, anti-inflammatory $(2.15 \mathrm{mg} / \mathrm{kg})$, anti-parasitic $(0.3 \mathrm{mg} / \mathrm{kg})^{210}$ and hepatoprotective $(10 \mathrm{mg} / \mathrm{kg})$ potential. ${ }^{211}$ Withanalide A has attracted interest due to its neuropharmacological properties of promoting synaptic and outgrowth reconstruction at a dose of $4.7 \mathrm{~g} / \mathrm{kg}$. ${ }^{212}$ WLD is therefore an important candidate for the therapeutic treatment of neurodegenerative diseases, like Alzheimer disease (AD), Parkinson's disease (PD), convulsions, cognitive function impairment, as it is able to reconstruct neural networks. ${ }^{213}$ The underlined molecular mechanisms studies on WA and WLD demonstrated modulation of multiple targets such as transcriptional factors, inflammatory cytokines, enzymes, growth factors, receptors and other targets suggesting promising drug candidates for cancer and neurological disorders ${ }^{214}$ Withania Sitoindosides and acylsteryl glucosides in Ashwagandha are anti-stress agents. Widely researched and proven for its effect on age related cognitive decline and dementia. WSG also exhibited an antidepressant effect, comparable with that induced by imipramine, in the forced swim induced 'behavioural despair' and 'learned helplessness' tests. ${ }^{215}$ In a study, a 30-days course of oral administration of a semipurified extract of the root of Withania somnifera consisting predominantly of withanolides and withanosides reversed behavioural deficits, plaque pathology, accumulation of $\beta$-amyloid peptides $(\mathrm{A} \beta)$ and oligomers in the brains of middle-aged and old APP/PS1 Alzheimer's disease transgenic mice. It was similarly effective in reversing behavioural deficits and plaque load in APPSwInd mice (line J20). ${ }^{216}$ The cell death caused by beta-amyloid was negated by treatment with withanamide from withania fruits. Molecular modeling studies showed that withanamides $\mathrm{A}$ and $\mathrm{C}$ uniquely bind to the active motif of betaamyloid (25-35) and suggest that withanamides have the ability to prevent the fibril formation. ${ }^{217}$ Systematic review on $W$. somnifera reveled successful inhibition of neurobehavioural abnormalities produced by different physical and chemical stimuli on oxidative stress in rodent brain. It also significantly decreased the increased LPO, protein carbonyl, AchE and nitrite levels in different parts of rodent brain. The natural cellular antioxidants (SOD, catalase and GPx) and the non-enzymatic antioxidant like GSH, ChAT and Ach alteration in the neuropathological environment were also considerably restored to normal by W. somnifera. ${ }^{209}$

Kapikacchu (Mucuna pruriens (Linn.))DC is a herbaceous twinning annual plant found all over India. Useful parts are root, leaves, seed and hairs (Figure 14). Mostly used as aphrodisiac, rejuvinative and nervine tonic in Ayurveda. ${ }^{218}$ it is extensively used in the treatment of parkinson's disease as it is a good source of L-3, 4 dihydroxyphenyl alanine (L-DOPA). ${ }^{219,220}$ It is known to increase secretion of semen and it act as a restorative and aphrodisiac in sexual dysfunction characterized by weakness or loss of sexual power. ${ }^{220}$ Seeds of M. pruriens possess antioxidant, hypoglycemic, lipid lowering and neuroprotective activities. ${ }^{221}$ The neuro protective activity may be due to Antioxidant, Dopaminergic potentials. ${ }^{222}$ Its seeds contain the alkaloids, mucunine, mucunadine, mucunadinine, prurienidine and nicotine, besides b-sitosterol, glutathione, lecithin, vernolic acid and gallic acid. Other bioactive substances include tryptamine, alkylamines, steroids, flavonoids, coumarins, cardenolides and metals like magnesium, copper, zinc, manganese and iron. ${ }^{223}$ Treatment with M. pruriens significantly ameliorated psychological stress and seminal plasma lipid peroxide levels along with improved sperm count and motility.22 The nigrostriatal portion of Parkinsonian mouse brain showed significantly increased levels of nitrite, malondialdehyde (MDA) and reduced levels of catalase besides improved the behavioral abnormalities as compared to the control. ${ }^{225}$

\section{DISCUSSION}

A review on selected rasayana herbs of Ayurveda revealed their potential to combat age related cognitive decline. The herbs reviewed were amalaki, hareetaki, haridra, manduka parni, anidri, yastimadhu, guduchi, shankhapushpi, vacha, jyotishmati, kushmanda, Jatamamsi, ashvagandha and Kapikacchu. Among them all herbs showed anti-oxidant and neuro-protective activities. Apart from anti-oxidant activity other factors that aid in anti-dementia and neuro protection are acetylcholine estarase inhibition, NMDA antagonism, Dopaminergic activity, removal of amyloidal plaques, inhibition of Tau aggregation, Folic acid, glutamic acid, Vitamin B etc. Rasayana herbs presenting with inhibition of AChE activity are hareetaki, amalaki, manduka parni, yashtimadhu, aindri, guduchi and ashvagandha. Predominant NMDA antagonist activity is shown by haridra, vacha, hareetaki and ashvagandha. Dopaminergic activity is seen in Kapikacchu, ashvagandha, guduchi and haridra. Reduction in amyloidal plaques and Tau aggregation is characteristic to shankhapushpi, haridra, hareetaki, amalaki, guduchi, ashvagandha and mandukaparni. Thus these rasayana herbs act by more than one way to break down the pathological path way in age related cognitive decline and hence can be potential contender in treatment of dementia. More- 
over, rasayana drugs enhance digestion, tissue metabolism, nutritional quality of plasma (rasa) and micro circulation. ${ }^{226}$ Besides this, most of the drugs discussed are medhya (nootropic) in nature with specific action as medhya (specific to nervous system) as well as their multidimensional utility. ${ }^{227}$ by virtue of the trace elements present in them. Getting deep into characteristics of drugs it may be postulated that regular usage of haridra, hareetaki, ${ }^{228-230}$ amalaki, vacha will go a long way to prevent Dementia \& related complications. Early usage of Aindri, mandukaparni, jyotishmati, jatamamsi, ashvagandha \& shankapushpi as single herb or in combination are beneficial in neuro degenerative condition, $1^{\text {st }} \& 2^{\text {nd }}$ stage of Dementia and Lewy bodies pathology for secondary prevention. Kapichacchu, Ashvagandha, Jatamamsi \& Haridra singly or in combination are better choice in treating dementia associated with Huntington's disorder. Guduchi, Vacha, Ashvagandha, Kushmanda, Yastimadhu and Haridra are helpful in vascular dementia. Yastimadhu, Aindri, Guduchi and Kushmanda are favourable in dementia due to toxic pathology like aluminium toxicity, food toxicity and radiation hazards etc. Kushmanda, Aindri, Guduchi, Yastimadhu, Jatamamsi and Ashvagandha are useful in dementia associated with anxiety, depression and personality changes.

In the first stage (1 to 2 year of onset) gradual onset of forgetfulness for recent events, become lost in familiar places, loss of track, time including day, month, year and season, difficulty in communication, finding words, making decisions, handling finance, mood changes, lack of interest and difficulty in carrying complex household activities. This stage at the onset is often overlooked as a part of normal aging process. Middle stage of the disease (2-5 years of the onset) presents with more precise progressive limitations and restrictions. Progressive forgetfulness for recent events and people's names, difficulty in comprehending time, date, place and events, may become lost in home and community, difficulty in speech, comprehension and communication. Assistance is required in personal care (toileting, washing and dressing). Inability to prepare food, cook, clean, shop, live alone safely without any assistance. Behaviour changes include inappropriate behaviours at home and community, wandering, repeated questioning, calling out, clinging, disturbed sleep and hallucinations. Last stage (after $5 \mathrm{yr}$ of onset) is of nearly total dependence and inactivity. Memory disturbances are very serious and the physical side of the disease becomes more obvious. Usually unawareness of time, place, people and events happening around prevails. Progressive dependence in self-care, sphinctural incontinence, changes in mobility, behaviour (aggression and nonverbal agitation including kicking, hitting, screaming and moaning etc). Other features may vary based on the co-morbidities and pathology. ${ }^{1}$

$1^{\text {st }}$ stage of Dementia can be managed on the lines of Kapha Dosha. In this stage, Haridra and Jyotismati can be used. Second stage of dementia is ideally managed on the lines of Pitta Dosha. In this stage, Mandookaparni, Aindri, Haridra and Yastimadhu are the better choice. Last stage of Dementia can respond well to Vata dosha management like Yastimadhu, Vacha, Jyotismati. Herbs like Amalaki, Haritaki, Jatamamsi, Guduchi, Ashvagandha, Kapikacchu, Kushmanda, Shankhapushpi can be used in all 3 stages because of its ability to pacify all 3 doshas.

\section{CONCLUSION}

Ample of evidences through experimental and pre-clinical studies have proven the efficacy of Ayurveda herbs in age related cognitive decline. In spite of their effective clinical use through ages valid document is sparse. The need of hour is to study the molecular basis of these herbs in humans.

\section{ACKNOWLEDGEMENT}

Authors are highly grateful to our revered President, Dr. D.Veerendra Heggade and Dr. B. Yashoverma, Secretary, SDM Educational Society for the encouragement. Authors highly regard the constant support of Dr. Shailaja U, Head, Department of Kaumarabhritya and Dr. Girish K J, Research co-ordinator SDM College of Ayurveda, Hassan. Authors thank Dr. B. Ravishankar, Director, SDM Centre for Research in Ayurveda and Allied Sciences for providing the research details on herbs.

\section{CONFLICT OF INTEREST}

The author declare no conflict of interest.

\section{ABBREVIATIONS USED}

WHO: World health organization; HIV: Human Immunodeficiency virus; cAMP: cyclic adenosine monophosphate; NMDA: N- methyl -D -aspartate; TBARS: Thiobarbituric acid reactive substance; SOD: Superoxide dismutase; AD: Alzheimer's Disease; $\mathbf{A} \beta$ : amyloid- $\beta$-protein, $\mathbf{H}_{2} \mathrm{O}_{2}$ : Hydrogen peroxide; PC12: Paracetamol; Ppm: parts per million; MAO: Monoamine oxidase; MAOA: Monoamine oxidase A; MAOB: Monoamine oxidase B; ATPase: Adenosine triphosphatase; DNA: Deoxy ribonucleic acid; C. asiatica: Centella asiatica; MDA: Methylene dioxy amphetamine; CeA: Centella asiatica; Alcl2: Aluminium chloride; $\mathrm{Na}+$ : Sodium; $\mathrm{K}^{+}$: Potassium, BDNF: Brain derived neurotrophic factor; GFAP: Glial fibrillary acidic protein; LDL: Low density, lipoproteins, CNS: Central nervous system; CP: Convolvulus pleuricaulis; mRNA: Messenger ribo nucleic acid; ABPP: Amyloid precursor protein; ROS: Reactive oxygen species; GABA: Gamma amino butyric acid; CCl: Carbon tetra chloride; HPA: Hypothalamic pituitary adrenal; FST: Forced swimming test; WLD: Withanolide; WA: Withaferin A; WSG: glycosides in Withania somnifera; APP/PS1: Amyloid precursor protein; GPx: Glutathione; GSH: Growth stimulating hormone.

\section{REFERENCES}

1. World Alzheimer Report 2009. London, Alzheimer Disease International 2009. Neurological disorders: public health challenges. Geneva, World Health Organization, 2006.

2. Blennow K, de Leon MJ, Zetterberg H. Alzheimer disease. Lancet. 2006; 368(9533):387-403

3. Waring SC, Rosenberg RN. Genome-wide association studies in Alzheimer disease. Arch Neurol. 2008;65(3):329-34.

4. American Psychiatric Association. Diagnostic and statistical manual of mental disorders (5 $5^{\text {th }}$ edition). Arlington, Va.: American Psychiatric Publishing; 2013.

5. Nadkarni, K.M., 1993. Indian Materia Medica. Popular Prakashan Private, Bombay,

6. Agnivesha. Caraka Samhita with Chakrapani's Ayurveda Deepika Teeka Acharya YT, editor. Varanasi: Choukhamba Samskrita Samsthana;1994. p. 38.

7. Grover IS, Kaur S. Effect of Emblica officinalis Gaertn: (Indian gooseberry) fruit extract on sodium azide and 4-nitro-O-phenylenediamine induced mutagenesis in Salmonella typhimurium. Indian Journal of Experimental Biology. 1989;27(3):207-09

8. Grover IS, Kaur S. Effect of Emblica officinalis Gaertn. (Indian gooseberry) fruit extract on sodium azide and 4-nitro-O-phenylenediamine induced mutagenesis in Salmonella typhimurium. Chemical Abstract 111, 17230h. 1989; 27(3):207-9.

9. Suresh K, Vasudevan DM. Augmentation of murine natural killer cell and antibody dependent cellular cytotoxicity activities by Phyllanthus emblica, a new immunomodulator. Journal of Ethnopharmacology. 1994;44(1):55-60.

10. Thakur CP, Mandal K. Effect of Emblica officinalis on cholesterol-induced atherosclerosis in rabbits. Indian Journal of Medical Research. 1984;79():142-6.

11. Thakur CP. Emblica officinalis reduces serum, aortic and hepatic cholesterol in rabbits. Experientia. 1985;41(3):423-4.

12. Mathur R, Sharma A, Dixit VP, Varma M. Hypolipidaemic effect of fruit juice of Emblica officinalis in cholesterol-fed rabbits. Journal of Ethnopharmacology. 1996;50(2):61-68.

13. Gulati RK, Agarwal S, Agrawal SS. Hepatoprotective studies on Phyllanthus emblica L. and quercetin. Indian Journal of Experimental Biology. 1995; 33(4):261-8.

14. Dwivedi Vibha, Tripathi K, Bipin Mutsuddi Mousumi and Lakhotia C Subhash. Ayurvedic Amalaki Rasayana and Rasa Sindoor suppress neurodegeneration in fly models of Huntington's and Alzheimer's diseases. Current science 2013;105(12):1711-23.

15. Govindarajan M, Vijayakumar P, Pushpangadan. Antioxidant approach to disease management and the role of 'Rasayana' herbs of Ayurveda. Journal of Ethno- 
pharmacology. 2005;99(2):165-78.

16. Saha S, Verma RJ. Antioxidant activity of polyphenolic extract of Terminalia chebula Retzius fruits. J Taibah Univ Sci. 2015. (article in press)

17. Grover IS, Bala S. Antimutagenic activity of T. chebula (myrob-lan) in Salmonella typhimurium, Ind. J. Exp. Biol. 1992;30(4):339-41.

18. Chattopadhyay RR, Bhattacharyya SK., Plant review Termina-lia chebula: an update. Pharmacog Rev. 2007;1(1):151-6.

19. Kapoor LD. Hand book of Ayurvedic Medicinal plants. CRC Press, Washington, DC, 2001;18-19.

20. Puri HS. 2003. 'Rasayana'-Ayurvedic herbs for longevity and rejuvenation. Tayor and Francis, London.

21. Naik GH, Priyadarsini Kl, Satav JG, Banavalikar MM, Sohoni DP, Biyani MK, Mohan H. Comparative antioxidant activity of individual herbal components used in Ayurvedic medicine. Phytochemistry. 2003;63(1):97-104.

22. Cheng HY, Lin TC, Yu KH, Yang CM, Lin CC. Antioxidant and free radical scavenging activities of Terminalia chebula. Biological and Pharmaceutical Bulletin 2003;26(9):1331-5

23. Nageswara rao S, Palaksha MN, Satish S, Ravishankar. The effects of Ethanolic Extract in Dried Fruits of Terminalia chebula on learning and memory in mice. Asian Journal of Biomedical and Pharmaceutical Sciences. 2013;3(20):59-62.

24. Chia Lin Chang, Che San Lin. Phytochemical Composition, Antioxidant Activity,and Neuroprotective Effectof Terminalia chebula Retzius Extracts. Evidence-Based Complementary and Alternative Medicine. 2012;1-7.

25. Part 1. Vol.. Delhi: Controller of Publications. The Ayurvedic Pharmacopoeia of India. 2004;83(4):62-3.

26. Aggarwal BB, Sundaram C, Malani N, Ichikawa H. "Curcumin: the Indian solid gold,". Advances in Experimental Medicine and Biology. 2007;59(5):1-75.

27. Ganguli M, Chandra V, Kamboh MI. et al, "Apolipoprotein E polymorphism and Alzheimer disease: the Indo-US crossnational dementia study.". Archives of Neurology. 2000;57(6):824-30.

28. Ng TP, Chiam PC, Lee T, Chua HC, Lim L, Kua EH. Curry consumption and cognitive function in the elderly. American Journal of Epidemiology. 2006;164(9):898-906

29. Park SY, Kim HS, Cho EK. et al. Curcumin protected PC12 cells against betaamyloid-induced toxicity through the inhibition of oxidative damage and tau hyperphosphorylation. Food and Chemical Toxicology. 2008:46(8):2881-7.

30. Zhang L, Fiala M, Cashman J. et al. Curcuminoids enhance amyloid- $\beta$ uptake by macrophages of Alzheimer's disease patients. Journal of Alzheimer's Disease. 2006;10(1):1-7.

31. Kim H, Park BS, Lee KG. et al. "Effects of naturally occurring compounds on fibril formation and oxidative stress of $\beta$-amyloid,." Journal of Agricultural and Food Chemistry. 2005;53(22):8537-41.

32. Ono K, Hasegawa K, Naiki H, Yamada M. Curcumin has potent anti-amyloidogenic effects for Alzheimer's $\beta$-amyloid fibrils in vitro. Journal of Neuroscience Research. 2004;75(6):742-50.

33. Yang F, Lim GP, Begum AN. et al. "Curcumin inhibits formation of amyloid $\beta$ oligomers and fibrils, binds plaques, and reduces amyloid in vivo,." Journal of Biological Chemistry. 2005;280(7):5892-901.

34. Shimmyo Y, Kihara T, Akaike A, Niidome T, Sugimoto H. Epigallocatechin-3 gallate and curcumin suppress amyloid beta-induced beta-site APP cleaving enzyme-1 upregulation. Neuro Report. 2008;19(13):1329-33.

35. Lin R, Chen X, LiW, Han Y, Liu P, Pi R. Exposure to metal ions regulates mRNA levels of APP and BACE1 in PC12 cells: blockage by curcumin. Neuroscience Letters. 2008:440(3):344-7.

36. Lim GP, Chu T, Yang F, Beech W, Frautschy SA, Cole GM. The curry spice curcumin reduces oxidative damage and amyloid pathology in an Alzheimer transgenic mouse. Journal of Neuroscience. 2001;21(21):8370-7.

37. Kim J, Lee HJ, Lee KW. Naturally occurring phytochemicals for the prevention of Alzheimer's disease. J Neurochem. 2010;112(6):1415-30.

38. Elaine Perry, Melanie-Jayne R. Howes. Medicinal Plants and Dementia Therapy: Herbal Hopes for Brain Aging?. CNS Neuroscience \& Therapeutics. 2011;17(6):683-98.

39. Garcia-Alloza M, Robbins EM, Zhang-Nunes SX. et al. Characterization of amyloid deposition in theAPPswe/PS1dE9 mouse model of Alzheimer disease. Neurobiology of Disease. 2006;24(3):516-24.

40. Cheng KK, Yeung CF, Ho SW, Chow SF, Chow AH, Baum L."Highly stabilized curcumin nanoparticles tested in an in vitro blood-brain barrier model and in Alzheimer's disease Tg2576 mice. The AAPS Journal. 2013;15(2):324-36.

41. Ma Z, Shayeganpour A, Brocks DR, Lavasanifar A, Samuel J. High-performance liquid chromatography analysis of curcumin in rat plasma: application to pharmacokinetics of polymeric micellar formulation of curcumin. Biomedica Chromatography. 2007;21(5):546-52.

42. Liu A, Lou H, Zhao L, Fan P. Validated LC/MS/MS assay for curcumin and tetrahydrocurcumin in rat plasma and application to pharmacokinetic study of phospholipid complex of curcumin. Journal of Pharmaceutical and Biomedical Analysis. 2006;40(3):720-27.

43. Yu ZF, Kong LD, Chen Y. Antidepressant activity of acqueous extracts of curcumalonga in mice. Journal of ethno pharmacology. 2002;83(1):161-65.
44. Shrinivas KK, Mohit KB, Mahendra B. Antidepressant activity of curcumin: involvement of serotonin and dopamine system. Psychopharmacology. 2008;201(3):435-42.

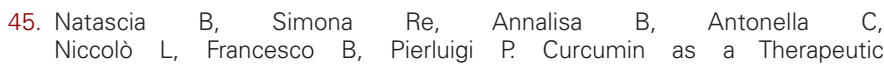
Agent in Dementia: A Mini Systematic Review of Human Studies. The Scientific World Journal. 2014;161-5

46. Kim DSHL, Park SY, Kim JY. Curcuminoids from curcuma long L. (Zingiberaceae) that protect PC12 rat pheochromocytoma and normal human umbilical vein endothelial cells from BA(1-42) insult. Neuroscience Letters. 2001;303(1):57-

47. Park SY, Kim DSHL. Discovery of natural products from curcuma longa that protects cells from beta-amyloid insult: a drug discovery effort against Alzheimer's disease. Journal of natural products. 2002;65(9):1227-31.

48. Kim DSHL and Kim JY. Total synthesis of calebin-A, preparation of its analogues, and their neuronal cell protectivity against amyloid insult. Bioorganic and Medicinal Chemistry Letters. 2001;11(18):2541-43.

49. Priyadarshini $\mathrm{KL}$. Free radical reactions of curcuin in membrane models. Free radicalbiology and medicine with anti oxidant activity. Journal of Ehno Pharmacology. 2000;71:23-43

50. scartezzini P, Speroni E. Review on some plants of Indian traditional medicine with antoxidant activity. Journal of Ethnopharmacology. 2000;71(1):23-43.

51. Das KC, Das K. curcumin (diferuloymethane), a singlet oxygen (O-1 (2)) quencher. Biochemical and Biophysical Research Communications 2002;295(1):62-6.

52. miquel J, Bernd A, Sempere JM, Diaz Alperi J, Ramirez A. The curcuma antioxidants: Pharmacological effects and prospects for future clinical use. A Review Archive of Gerentology and Geriatrics. 2002;34(1):37-46.

53. Sharma PC, Yelne MB, Dennis TJ. Database on Medicinal plants used in Ayurveda and Sidha. Vol. 1. New Delhi: CCRAS, Dept. of AYUSH, Ministry of Health and Family Welfare. Govt of India. 2000;264-79.

54. Acharya YT, editor. Caraka Samhita with Chakrapani's Ayurveda Deepika Teeka. Varanasi: Choukhamba Samskrita Samsthana. Agnivesha. 1994;385.

55. Sharma PC, Yelne MB, Dennis TJ. Database on Medicinal plants used in Ayurveda and Sidha. New Delhi: CCRAS, Dept. of AYUSH, Ministry of Health and Family Welfare, Govt. of India. 2005:1:265-6.

56. Ramanathan M, Sivakumar S, Anand Vijayakumar PR, Saravanababu C Rathinavel Pandian P. Neuroprotective evaluation of standardized extracts of Centella asiatica in monosodium glutamate treated rats. Indian J Exp Biol. 2007;45(5):425-31. [PubMed: 17569283]

57. Anbuganapathi GA. Synergetic effect of Vallarai and Brahmi on learning ability of albino mice and school children. Ootacamund: Paper presented at the International Seminar on Recent Trends in Pharmaceutical Sciences. 1995. pp. 18-20.

58. Mohandas Rao KG, Muddanna Rao S, Gurumadhva Rao S. Centella asiatica (L.) Leaf Extract Treatment during the Growth Spurt Period Enhances Hippocampal CA3 Neuronal Dendritic Arborization in Rats. eCAM. 2006:3(3):349-57. [PMCID: PMC1513148] [PubMed: 16951719]

59. Visweswari G, Sivaprasad K, Lokanatha V, Rajendra W. The antiepileptic effect of Centella asiatica on the activities of $\mathrm{Na}^{+} / \mathrm{K}^{+}, \mathrm{Mg} 2^{+}$and $\mathrm{Ca} 2^{+}$-ATPases in rat brain during pentylenetetrazol-induced epilepsy. Indian J Pharmacol. 2010;42(2):82-6. [PMCID: PMC2907020] [PubMed: 20711371]

60. Russo A, Borrelli F. Bacopa monniera, a reputed nootropic plant: An overview. Phytomed. 2005;12(4):305-17.

61. Kumar A, Kulkarni SK. Protective effect of BR-16A, a polyherbal preparation against social isolation stress: Possible GABAergic mechanism. Phytother Res. 2006;20(7):538-41. [PubMed: 16691632]

62. Anand T, Naika M, Kumar PG, Khanum F. Antioxidant and DNA Damage Preventive Properties of Centella asiatica (L) Urb. Phcog J. 2010;2(17):53-8.

63. Veerendra Kumar MH, Gupta YK. Effect of Centella asiatica on cognition and oxidative stress in an intracerebroventricular streptozotocin model of Alzheimer's disease in rats. Clin Exp Pharmacol Physiol. 2003;30(5-6):336-42.

64. Mohandas Rao KG, Muddanna Rao S, Gurumadhva Rao S. Enhancement of Amygdaloid Neuronal Dendritic Arborization by Fresh Leaf Juice of Centella asiatica (Linn) During Growth Spurt Period in Rats. Evid Based Complement Alternat Med. 2009 Jun;6(2):203-10.

65. Chen Y, Han T, Qin L, Rui Y, Zheng H. Effect of total triterpenes from Centella asiatica on the depression behavior and concentration of amino acid in forced swimming mice. Zhong Yao Cai. 2003:26(12):870-3

66. Oruganti M, Roy B, Singh K, Prasad R, Kumar S. Safety Assemment of Centella asiatica in albino rats. Phcog J. 2010;2(16):5-11.

67. Sharma PV. Dravyaguna Vijnana. Varanasi: Chaukhambha Bharati Academ (in Hindi). 1995;2:6-8.

68. Sharma PC, Yelne MB, Dennis TJ. Database on Medicinal plants used in Ayurveda and Sidha. Vol. 1. New Delhi: CCRAS, Dept. of AYUSH, Ministry of Health and Family Welfare, Govt. of India. 2000. p. 93-101.

69. Bhavaprakasha. Bhavaprakasha Nighantu, 1 st ed. Varanasi: Chaukhamba Publishers; 2007. p. 131

70. Aithal HN, Sirsi M. Pharmacological investigation of Herpestis monneri. Indian J Pharmcol. 1961;23:2-5. 
71. Malhotra CL, Das PK. Pharmacological studies of Herpestis monneri. Indian J Med Res. 1959;47(3):244-305.

72. Singh HK, Dhawan BN. Neuropsychopharmacological effects of the Ayurvedic Nootropic Bacopa monneri Linn. (Bramhi). Indian J Pharmacol. 1997;29(5):359-65.

73. Sumathy T, Subramanian S, Govindaswamy S, Balakrishna K, Veluchamy G Protective role of Bacopa monniera on morphine-induced hepatotoxicity in rats. Phytother Res. 2001;15(7):643-5.

74. Raghav S, Singh H, Dalal PK, Srivastava JS, Asthana OP. Randomized controlled trial of Bacopa monniera extract in age- associated memory impairment. Indian J Psychiatry. 2006;48(4):238-42.

75. Tripathi YB, Chaurasia S, Tripathi E, Upadhyay A, Dubey GP. Bacopa monniera Linn. as an antioxidant: Mechanism of action. Indian J Exp Biol. 1996;34(6):523-6.

76. Devasagayam TP, Tilak JC, Boloor KK, Sane KS, Ghaskadbi SS, Lele RD. Free radicals and antioxidants in Human Health: Current status and future prospects. J Assoc Physicians India. 2004;52(794804):4

77. Bhattacharya SK, Bhattacharya A, Kumar A, Ghosal S. Antioxidant activity of Bacopa monniera in rat frontal cortex, striatum and hippocampus. Phytother Res. 2000;14(3):174-9.

78. Rehni AK, Pantlya HS, Shri R, Singh M. Effect of Chlorophyll and aqueous extracts of Bacopa monniera and Valeriana wallichii on ischemia and reperfusion induced cerebral injury in mice. Indian J Exp Biol. 2007;45:764-9.

79. Maciuk A, Bouchet MJ, Mazars G, Um BH, Anton R. Nootropic (Medhya) plants from ayurvedic pharmacopeia. Etudes chimiques et pharmacologiques 2002;402-11.

80. Girish SA, Barabde U, Wadodkar S, Dorle A. Effect of Bramhi Ghrita, an polyherbal formulation on learning and memory paradigms in experimental animals. Indian J Pharmacol. 2004;36(3):159-62.

81. Hou CC, Lin SJ, Cheng JT, Hsu FL. Bacopasaponin G and bacopasides A, B, and C from Bacopa monniera. J Nat Prod. 2002;65(12):1759-63.

82. Chakravarty AK, Garai S, Masuda K, Nakane T, Kawahara N. Bacopasides III-V: Three new triterpenoid glycosides from Bacopa monniera. Chem Pharm Bull. 2003;51(2):215-7.

83. Choudhari DK, Parmar D, Kakkar P, Shukla R, Seth PK, Srimal RC. Antistress effects of bacosides of Bacopa monneri: Modulation of Hsp70 expression, superoxide dismutase and cytochrome P450 activity in rat brain. Phytother Res. 2002;16(7):639-45.

84. Vohora D, Pal SN, Pillai KK. Protection from phenytoin induced cognitive deficits by Bacopa monnieri, a reputed Indian nootropic plant. J Ethnopharmacol. 2000;71(3):383-90

85. Shukla B, Khanna NK, Godhwani L. Effect of Brahmi Rasayan on the central nervous system. J Ethnopharmacol. 1987;21(1):65-74

86. Anbarasi K, Vani G, Balakrishna K, Devi CS. Effect of Bacoside A on Brain antioxidant status in cigarette smoke exposed rats. Life Sci. 2006;78(12):1378.

87. Kar A, Panda S, Bharati S. Relative efficacy of three medicinal plant extracts in the alteration of thyroid hormone concentrations in male mice. J Ethnopharmacol. 2002;81(2):281-5

88. Agrawal A, Rajamanickam GV, Dubey GP. Ayurvedic Drugs in the Prevention and Management of Neuro-degenerative Disorders. 10-AYU-N10.PM70 P 20 4-2006 I.

89. Saraf MK, Prabhakar S, Khanduja KL, Anand A. Bacopa monniera Attenuates Scopolamine-Induced Impairment of Spatial Memory in Mice. EvidenceBased Complementary and Alternative Medicine. 2011; Article ID 236186.

90. Uabundit N, Wattanathorn J, Mucimapura S, Ingkaninan K. Cognitive enhancement and neuroprotective effects of Bacopa monnieri in Alzheimer's disease model. J Ethnopharmacol. 2010;127(1):26-31.

91. Jyoti A, Sethi P, Sharma D. Bacopa monniera prevents from aluminium neurotoxicity in the cerebral cortex of rat brain. J Ethnopharmacol. 2007;111(1):56-62.

92. Saini N, Singh D, Sandhir R. Neuroprotective Effects of Bacopa monnieri in Experimental Model of Dementia. Neurochem Res. 2012;37(9):1928-37.

93. Das A, Shanka G, Nath C, Pal R, Singh S, Singh H. A comparitaive study in rodents of standardized extracts of Bacopa monniera and Ginkobiloba : anticholinesterase and cognitive enhancing activities. Pharmacol Biochem Behav. 2002;73(4):893-900.

94. Arpita Konar,1 Akash Gautam, 2, M. K. Thakur. Bacopa monniera (CDRI-08) Upregulates the Expression of Neuronal and Glial Plasticity Markers in the Brain of Scopolamine Induced Amnesic Mice. Evidence-Based Complementary and Alternative Medicine. 2015. Article ID 837012.pp1-9.

95. Calabrese C, Gregory WL, Leo M, Kraemer D, Bone K, Oken B. Effects of a Standardized Bacopa monnieri Extract on Cognitive Performance, Anxiety, and Depression in the Elderly: A Randomized, Double-Blind, Placebo-Controlled Trial. Journal of Alternative and Complementary Medicine. 2008;14(6):707-713.

96. Goswami S, Saoji A, Kumar N, Thawani V, Tiwari M, Thawani M. Effect of Bacopa monnieri on Cognitive functions in Alzheimer's disease patients. International Journal of Collaborative Research on Internal Medicine \& Public Health. 2011:3(4):285-293

97. Sharma PC, Yelne MB, Dennis TJ. Database on Medicinal plants used in Ayurveda and Sidha. Vol. 3. New Delhi: CCRAS, Dept. of AYUSH, Ministry of Health and Family Welfare, Govt. of India. 2005. pp. 561-617.
98. Hatano T, Shintani Y, Shiota S, Tsuchiya T, Yoshida T. Phenolic constituents of licorice. VIII. Structures of glicophenone and glycoisofl avanonem and effects of licorice, phenolics on Methicillin- resistant Staphylococcus aureus. Chem Pharm Bull. 2000;48(9):1286-92. [PubMed: 10993226]

99. Ishii Y, Fuji Y. Effects of FM 100, a fraction of licorice root on serum gastrin concentration in rats and dogs. Jpn J Pharmacol. 1982:32(1):23-7. [PubMed: 7087261]

100. Kuroda M, Mimaki Y, Sashida Y, Mae T, Kishida H, Nishiyama H, et al. Phenolics with PPAR- Ligand binding activity obtaind from Licorice (Glycyrrhiza uralensis roots) and ameliorative effects of Glycyrin on genetically diabetic KK-Ay mice. Bioorg Med Chem Lett. 2004;13(24):4267-72. [PubMed: 14643306]

101. Kanda H, Sakurai M, Arima K. Licorice of "Shukuyaku Kanzou tou" induced pseudoaldosteronism. Hinyokika Kiyo. 2004;50(3):215-7. [PubMed: 15148778]

102. Yoshida S, Takayama Y. Licorice induced hyperkalemia as a treatable cause of dropped head syndrome. Clin Neurol Neurosurg. 2003;105(4):286-7. [PubMed: 12954548]

103. Sigurjonsdottir HA, Franzson L, Manhem K, Ragnarsson J, Sigurdsson G, Wallerstedt S. Licorice induced rise in Blood pressure, a linear dose response relationship. J Hum Hypertens. 2001;15(8):549-52. [PubMed: 11494093]

104. Nussberger J. Investigating mineralocorticoids hypertension. J Hypertension. 2003;2(Suppl):525-30.

105. Ravichandra V, Ahalyadevi, Adiga S. Evaluation of the effect of Glycyrrhiza glabra Linn. root extract on spatial learning and passive avoidance response in rats. Indian Drugs. 2007;44(3):214-9.

106. Toshio F, Kazue S, Taro N. Preliminary evaluation of anti nephritis and radical scavenging activities of glabridin from Glycyrrhiza glabra Linn. Fitotherapia. 2003; 74:624-9.

107. Zhan C, Yang J. Protective effects of isoliquiritigenin in transient middle cerebral artery occlusion induced focal cerebral ischemia in rats. Pharmacol Res. 2006;53(3):303-9. [PubMed: 16459097]

108. Vaya J, Belinky PA, Aviram M. Structural aspects of the inhibitory effect of glabridin on LDL oxidation. Free Rad Biol Med. 1998;24(9):1419-29. [PubMed: 9641259]

109. Muralidharan P, Balamurugan G, Venu Babu. Cerebroprotective effect of Glycyrrhiza glabra Linn. root extract on Hypoxic rats. Bangladesh J Pharmacol. 2009;4(1):60-4.

110. Devasagayam TP, Tilak JC, Boloor KK, Sane KS, Ghaskadbi SS, Lele RD. Free radicals and antioxidants in Human Health: Current status and future prospects. J Assoc Physicians India. 2004;52:(794804):4. [PubMed: 15909857]

111. Rathee $\mathrm{P}, \mathrm{Chaudhary} \mathrm{H}$, Rathee $\mathrm{S}$, Rathee D. Natural memory boosters. Phcog Rev. 2008;2(4):249-56.

112. Dhingra D, Parle M, Kulkarni SK. Memory enhancing activity of Glycyrrhiza Glabra in mice. J Ethnopharmacol. 2004;91(2):361-5. [PubMed: 15120462]

113. Hasanein P. Glabridin as a major active isoflavan from Glycyrrhiza glabra (licorice) reverses learning and memory deficits in diabetic rats. Acta Physio Hung. 2011;98(2):221-30.

114. Cui YM, Ao MZ, LiW, Yu LJ. Effect of glabridin from Glycyrrhiza glabra on learning and memory in mice. Planta Med. 2008;74(4):377-80

115. Sharma PC, Yelne MB, Dennis TJ. Database on Medicinal plants used in Ayurveda and Sidha. Vol. 3. New Delhi: CCRAS, Dept. of AYUSH, Ministry of Health and Family Welfare, Govt. of India; 2005. pp. 256-81.

116. Nayampalli S, Ainapure SS, Nadkarni PM. Study of antiallergic acid Bronchodilator effects of Tinospora cordifolia. Indian J Pharm. 1982;14 (1982):64-6.

117. Zhao TF, Wang $X$, Rimando AM, Che C. Folkloric medicinal plant: Tinospora sagittata var.cravaniana and Mohonia bealei. Planta Med. 1991;57(5):505-3. [PubMed: 1798808]

118. Singh SS, Pandey SC, Srivastava S, Gupta VS, Patro B, Ghosh AC. Chemistry and Medicinal properties of Tinospora cordifolia (Guduchi) Indian J Pharmacol. 2003;35(2):83-91.

119. Avinash KR, Manohar GM, Saibal KB. Rubia cordifolia, Fagonia cretica Linn. and Tinospora cordifolia exert neuroprotection by modulating the antioxidan system in rat hippocampal slices subjected to oxygen glucose deprivation BMC Complement Altern Med. 2004;4(1):11. [PMCID: PMC514713] [PubMed 15310392]

120. Chulet R, Pradhan P. A review on Rasayana. Phcog Rev. 2009;3(6):229-34.

121. Sharma $V$, Pandey D. Protective role of Tinospora cordifolia against leadinduced hepatotoxicity. Toxicol Int. 2010;17(1):12-7. [PMCID: PMC2964743] [PubMed: 21042467

122. Agarwal A, Malini S, Bairy KL, Rao MS. Effect of Tinospora cordifolia on Learning and Memory in normal and memory deficit rats. Indian J Pharmacol. 2002;34(5):339-49

123. Singh RP, Banergee S, Kumar PV, Raveesha KA, Rao AR. Tinospora cordifolia induces enzymes of carcinogen/ drug metabolism and antioxidant System, and inhibits lipid peroxidation in mice. Phytomedicine. 2006:13(1):74-84 [PubMed: 16360936]

124. Stanely M, Prince P, Menon VP. Antioxidant action of Tinospora cordifolia root extract in alloxan diabetic rats. Phytother Res. 2001;15(3):213-8. [PubMed 11351355] 
125. Patil M, Patki P, Kamath HV, Patwardhan B. Antistress activity of Tinospora cordifolia (Willd) Meirs. Indian drugs. 1997;34(4):211-5.

126. Yalla Reddy Y, Mohana Lakshmi S, Saravana KA. Review on Effect of Natural Memory Enhancing Drugs On Dementia. Int J Phytopharmacol. 2010;1:1-7.

127. Asuthosh A, Malini S, Bairy KL, Muddanna SR. Effect of Tinospora cordifolia on learning and memory in normal and memory deficits rats. Indian J Pharmacol. 2000;34(5):339-49.

128. Prince PS, Kamalakkannan N, Menon VP. Restoration of antioxidant defence by ethanolic Tinospora cordifolia root extract in alloxan-induced diabetic liver and kidney. Phytother Res. 2004;18(9):785-7. [PubMed: 15478189]

129. Devasagayam TP, Tilak JC, Boloor KK, Sane KS, Ghaskadbi SS, Lele RD. Free radicals and antioxidants in Human Health: Current status and future prospects. J Assoc Physicians India. 2004;52:(794804):4. [PubMed: 15909857]

130. Manjrekar PN, Jolly Cl, Narayanan S. Comparative studies of the immunomodulatory activity of Tinospora cordifolia and Tinospora sinensis. Fitoterapia. 2000;71(3):254-7. [PubMed: 10844163]

131. Bairy KL, Rao Y, Kumar KB. Efficacy of Tinospora cordifolia on Learning and Memory in Healthy Volunteers: A Double- Blind, Randomized, Placebo Controlled Study. Iranian Journal of Pharmacology and Therapeutics. 2004;3(2):5760.

132. Agarwal A, Malini S, Bairy KL, Rao MS. Effect of Tinospora Cordifolia on earning and Memory in Normal and Memory Deficit Rats. Indian Journal of Pharmacology. 2002;34(5):339-49.

133. Upadhyay A, Kumar K, Kumar A, Mishra H. Tinospora Cordifolia (Willd.) Hook. F. and Thoms. (Guduchi) Validation of the Ayurvedic pharmacology through experimental and clinical studies. Int J Ayurveda Res. 2010;1(2):112-21.

134. Mutalik, Madhav, Mutalik, Maitreyee. Tinospora cordifolia: Role in depression, cognition and memory. Australian Journal of Medical Herbalism. 2011;23(4):168-73.

135. Billore KV, Yelne MB, Dennis TJ, Chaudhari BG. In: Database on Medicinal plants used in Ayurveda and Sidha. Joshi A, Prabhune YS, editors. Vol. 7. New Delhi: CCRAS, Dept. of AYUSH, Ministry of Health and Family Welfare, Govt. of India; 2005. pp. 433-41.

136. Part 1. Vol. 2. Delhi: Controller of Publications, Civil Lines; 1999. The Ayurvedic Pharmacopoeia of India; p. 155

137. Bhatnagar M, Sisodia SS, Bhatnagar R. Antiulcer and antioxidant activity of Asparagus racemosus Willd and Withania somnifera Dunal in rats. Ann NY Acad Sci. 2005;1056(1):261-78. [PubMed: 16387694]

138. Kumar A, Kulkarni SK. Protective effect of BR-16A, a polyherbal preparation against social isolation stress: Possible GABAergic mechanism. Phytother Res. 2006;20(7):538-41. [PubMed: 16691632]

139. Rajagopalan V. Seminar on research in Ayurveda and Sidha. New Delhi: CCRAS; 1995.

140. Kalra Sanjeev. A study on the effect of Shankhapushpi compound and Satwavajaya Chikitsa in Chittodvega (generalized anxiety disorders) Dept. of Post Graduate studies in Manasa Roga, SDM College of Ayurveda and Hospital. Hassan, Rajiv Gandhi University of Health Sciences, Karnataka. 2006

141. Parsania S. A clinical study on the role of Jaladhara and Shankhapushpi (Convolvulus pleuricaulis) in the management of Chittodvega (anxiety disorder) Jamnagar: Dept. of Kayachikitsa, IPGT and RA, Gujarat Ayurveda university; 2001:35-7.

142. Kumar V. Potential Medicinal Plants for CNS Disorders: An Overview. Phytother Res. 2006;20(12):1023-35. [PubMed: 16909441]

143. Indurwade NH, Biyani KR. Evaluation of comparative and combined depressive effect of Brahmi, Shankhpushpi and Jatamansi in mice. Indian J Med Sci. 2000;54(8):339-41. [PubMed: 11143748]

144. Sharma K, Bhatnagar M, Kulkarni SK. Effects of Convolvulus pluricaulis choisy and Asparagus racemosus Willd. on learning and memory in young and old mice: A comparative evaluation. Journal of Experimental Biology. 2010;48(5):479-485.

145. Bihaqi SW, Sharma M, Singh AP, Tiwari M. Neuroprotective role of Convolvulus pluricaulis on aluminium induced neurotoxicity in rat brain. Journal of Ethnopharmacology. 2009;124(3):409-415.

146. Syed Waseem Bihaqi, Avninder Pal Singh, and ManishaTiwari. Supplementation of Convolvulus pluricaulis attenuates scopolamineinduced increased tau and Amyloid precursor protein (AßPP) expression in rat brain. Indian J Pharmacol. 2012-44(5):593-598.

147. Sharma PC, Yelne MB, Dennis TJ. Database on Medicinal plants used in Ayurveda and Sidha. Vol. 2. New Delhi: CCRAS Dept. of AYUSH, Ministry of Health and Family Welfare, Govt. of India; 2005. pp. 281-91.

148. Bhavaprakasha Nighantu. $1^{\text {st }}$ ed. Varanasi: Chaukamba Publishers; 2007. Bhavamishra; p. 32.

149. Yong QT, Yao ZC, Da GW, Xian MZ, Xiao JH. Sesquiterpenoids from Celastrus paniculatus. J Nat Prod. 1993;56(1):122-5.

150. Kumar MH, Gupta YK. Antioxidant property of Celastrus paniculatus Willd. A possible mechanism in enhancing cognition. Phytomedicine. 2002;9(4):302-11. [PubMed: 12120811]

151. Kalpana SP, Jayaprakash Effect of Celastrus paniculatus Willd.Seed on adjuvant induced arthritis. Phcog Mag. 2007;3(11):177.

152. Gattu M, Boss KL, Terry AV, Buccafusco JL. Reversal of scopolamine induced deficits in navigational memory performance by the seed oil of Celastrus paniculatis. Pharmacol Biochem Behav. 1995;57(4):793-9. [PubMed: 9259008]

153. Lekha G, Kumar BP, Rao SN, Arockiasamy I, Mohan K. Cognitive enhancement and Neuroprotective effect of Celastrus paniculatus Willd. seed oil (Jyothismati oil) on male Wistar rats. Journal of Pharmaceutical Science and Technology 2010;2(2):130-8

154. Part 1. Vol. 4. Delhi: Controller of Publications; 2004. The Ayurvedic Pharmacopoeia of India; pp. 62-3.

155. Sharma PV. Dravyaguna-vijnana. Vol. 2. Varanasi: Chaukhambha Bharati Academy; 1995. pp. 4-17. in Hindi.

156. Battu GR, Mamidipalli SN, Parimi R, Viriyala RK, Patchula RP, Mood LR. Hypoglycemic and anti-hyperglycemic effect of alclholic extract of Benincasa hispida in normal and in alloxan induced diabetic rats. Phcog Mag. 2007;3(10): 101

157. Bhalodia YS, Patel NJ, Patel RK, Vaghasiya JD, Jivani NP, Sheth NR. Benincasa cerifera ameliorates Renal ischemia/Reperfusion injury in hyperlipidemic rat. Phcog Res. 2009;1 (6):406-9.

158. Lim SJ. Effects of fractions of Benincasa hispida on antioxidant status in Streptozotocin induced Diabetic rats. Korean J Nutr. 2007;40(4):295-302.

159. Sharma PC, Yelne MB, Dennis TJ. Database on Medicinal plants used in Ayurveda and Sidha. Vol. 1. New Delhi: CCRAS, Dept. of AYUSH, Ministry of Health and Family Welfare, Govt. of India; 2000. pp. 469-95.

160. Lai XY, Liang H, Zhao YY. A survey of the studies on chemical constituents and pharmacological activities of Acorus plants. Zhongguo Zhong Yao Za Zhi. 2002;27(3):161-5. 198. [PubMed: 12807142]

161. Shukla PK, Khanna V, Ali M, Maurya R, Khan MY, Srimal RC. Neuroprotective effect of Acorus calamus against middle cerebral artery occlusion-induced ischaemia in rat. Hum Exp Toxicol. 2006;25(4):187-94. [PubMed: 16696294]

162. Koo BS, Park KS, Ha JH, Park JH, Lim JC, Lee DU. Inhibitory effects of the fragrance inhalation of essential oil from Acorus gramineus on central nervous system. Biol Pharm Bull. 2003;26(7):978-82. [PubMed: 12843622]

163. Mukherjee PK, Kumar V, Mal M, Houghton PJ. In vitro acetylcholinesterase inhibitory activity of the essential oil from Acorus calamus and its main constituents. Planta Med. 2007;73(3):283-5. [PubMed: 17286241]

164. Mazza G. Gas chromatographic and mass spectrometry studies of the constituents of the rhizome of Acorus calamus II, The volatile constituents of essential oil. J Chromatogr. 1985;328:179-94

165. Willamson EM, Evans FJ. Potter's new cyclopedia of botanical drugs and preparations. Walden, Essex: Saffron Walden; 1988.

166. Jayaraman R, Anitha T, Vishal DJ. Analgesic and Anticonvulsant effects of Acorus calamus roots in mice. Int J Pharm Tech Res. 2010;2(1):552-5.

167. Palani S, Raja S, Praveen KR, Venkadesan D, Devi K, Sivaraj A, et al. Therapeutic efficacy of antihepatotoxic and antioxidant activities of Acorus calamus on acetaminophen- induced toxicity in rats. Int Journal Integr Biol. 2009;7(1):39-44.

168. Acuna UM, Atha DE, Ma J, Nee MN, Kennelly EJ. Antioxidant capacities of ten edible North American plants. Phytother Res. 2002;16(1):63-5. [PubMed: 11807968]

169. Shahin SA, Naresh K, Abhinav L, Angad S, Hallihosur S, Abhishek S, et al. Review Indian medicinal herbs as sources of antioxidants. Food Res Int. 2008;41(1):1-15.

170. Aqil F, Zahin M, Ahmad I. Antimutagenic activity of methanolic extracts of four ayurvedic medicinal plants. Indian J Exp Biol. 2008;46(9):668-72. [PubMed: 18949897]

171. Ignacimuthu S, Ayyanar M, Sivaraman S. Ethnobotanical investigations among tribes in Madurai District of Tamil Nadu (India) J Ethnobiol Ethnomed. 2006;2(s1):25. PMCID: PMC1475842] [PubMed: 16689985]

172. Chellaiah M, Muniappan A, Nagappan R, Savarimuthu I. Medicinal plants used by traditional healers in Kancheepuram District of Tamil Nadu, India. J Ethnobio Ethnomed. 2006;2(1):43. [PMCID: PMC1615867] [PubMed: 17026769]

173. Fozdar NG, Doongaji, Bauadia VN, Vahia NS. Preliminary of report an indegenious drug Acorus calamus in psychiatric disorders. Indian J Psychiatry. 1962;4(1):12.

174. Pulok kumar muKherjee, Venkatesan kumar, Mainak mal, Peter J Haughton. Invitro acetylcholinesterase inhibitory activity of the essential oil from Acorus calamus and its main constituents. Letter. Planta Med. 2007;73(3):283-5.

175. Vijayapandi et al., Afr J Tradit Complement Altern Med. (2013);10(1):95-101

176. Chen Huanga, c, 1, WeiGuang Lic, 1, XiaoBing Zhangb, Li Wanga, TianLe Xuc, Dazheng Wua, , Yong L. Alphaasarone from Acorus gramineus alleviates epilepsy by modulating AType GABA receptors. Neuropharmacology. 2013;65:1-11.

177. Ravindran PN, Balachandran I. Under utilized medicinal spices. Spice India. 2004;17(12):2-14.

178. Riaz M, Chaudhary FM. Chemistry of medicinal plants of genus acorus (family Aracae) Hamdard Medicus. 1995;38:50-62.

179. Manikandan S, Srikumar R, Jeya Parthasarathy N, Sheela Devi R: Protective effect of Acorus calamus Linn on free radical scavengers and lipid peroxidation in discrete regions of brain against noise stress exposed rat. Biol Pharm Bull. 
Kulkarni et al.: Rasayana herbs to treat age related cognitive decline

2005,28(12):2327-30

180. Tippani R, Porika M, Rao AV, Abbagani S, Yellu NR, Tammidala C: Analgesic activity of root extract of Acorus calamus Linn. Pharmacologyonline. 2008;3:240-3.

181. Yang L, Li S, Huang Y, Liang J, Wang Y: Effects of Acorus gramineus and its component, alpha-asarone, on apoptosis of hippocampal neurons after seizure in immature rats. Neural Reg Res. 2008;3(1):19-24

182. Geetha RK, Vasudevan DM: Inhibition of lipid peroxidation by botanical extracts of Ocimum sanctum: In vivo and in vitro studies. Life Sci. 2004;76(1):21-8

183. Hazra R, Ray K, Guha D: Inhibitory role of Acorus calamus in ferric chlorideinduced epileptogenesis in rat. Hum Exp Toxicol. 2007;26(12):947-53.

184. Shukla PK, Khanna VK, Ali MM, Maurya R, Khan MY, Srimal RC: Neuroprotective effect of Acorus calamus against middle cerebral artery occlusion-induced ischaemia in rat. Hum Exp Toxicol. 2006;25(4):187-94.

185. Young W: Role of calcium in central nervous system injuries. J Neurotrauma 1992;9:9-25

186. Gilani AU, Shah AJ, Ahmad M, Shaheen F: Antispasmodic effect of Acorus calamus Linn. is mediated through calcium channel blockade. Phytother Res. 2006;20(12):1080-4.

187. Muthuraman, Singh N. Attenuating effect of Acorus calamus extract in chronic constriction injury induced neuropathic pain in rats: an evidence of anti-oxidative, anti-inflammatory, neuroprotective and calcium inhibitory effects. BMC Complementary and Alternative Medicine. 2011;11(1):24.

188. Ilaiyaraja N, Dongzagin Singsit, Farhath K. Effect of rhizome extract of Acorus calamus on depressive condition induced by forced swimming in mice. Inter national Journal of phytomedicine. 2012;4(3):319-25.

189. Bellore KV, Yelne MB, Dennis TJ, Chaudhari BG. Database on Medicinal plants used in Ayurveda and Sidha. Vol. 7. New Delhi: CCRAS, Dept. of AYUSH, Ministry of Health and Family Welfare, Govt. of India; 2005. pp. 135-57.

190. Bhavaprakasha Nighantu. $1^{\text {st }}$ ed. Varanasi: Chaukamba Publishers; 2007 Bhavaprakasha; p. 65.

191. Bagchi A, Oshima Y, Hikino H. Neoligans and lignans of Nardostachys Jatamans Roots. Planta Med. 1991;57(1):96-7. [PubMed: 17226134]

192. Uniyal MR, Issar RK. Commercially and traditionally important medicinal plants of Mandakini valley of Uttarkhand Himalayas. J Res Indian Med. 1969;4:83-96.

193. Chatterjee A, Basak B, Saha M, Dutta U, Mukhopadhyay C, Banerji J, et al. Structure and Stereo-chemistry of Nardostachysin, A New Terpenoid ester constituent of the Rhizomes of Nardostachys Jatamansi. J Nat Prod. 2000 63(11):1531-3. [PubMed: 11087600]

194. Joshi H. Parle M. Nardostachys jatamansi improves learning and memory in mice. J Med Food. 2006;9(1):113-118. [PubMed: 16579738]

195. Ahamad M, Saleem S, Ahamad AS, Ansari MA, Yousuf S, Hoda MN, et al. Neuroprotective effect of Withania sominifera on 6-hydroxydopamine induced Parkinsonism in rats. Hum Exp Toxicol. 2005;24(3):137-47. [PubMed: 15901053]

196. Mukherjee PK, Kumar V, Houghton PJ. Screening of Indian medicinal plants for acetylcholinesterase inhibitory activity. Phytother Res. 2007;21(12):1142-5.

197. Joshi H, Parle M. Nardostachys jatamansi improves learning and memory in mice. J Med Food. 2006;9(1):113-8.

198. Karkada G, Shenoy KB, Halahalli H, Karanth KS. Nardostachys jatamans extract prevents chronic restraint stress-induced learning and memory deficits in a radial arm maze task. J Nat Sci Biol Med. 2012;3(2):125-32.

199. Faiyaz A, Narendra Sharath Chandra JNb. Asna Urooja and Rangappa K.S. In vitro antioxidant and anticholinesterase activity of Acorus calamus and Nardostachys jatamansi rhizomes. Journal of Pharmacy Research. 2009:2(5):830-33.

200. Ali A, Dua Y, Siddiqui AW, Sultana S, Rafiullah MR. Inhibition of benzoy peroxide-induced cutaneous oxidative stress, toxicity and ear edema in mice by Nardostachys Jatamansi. Pharm Biol. 2005;43(6):533-9.

201. Muzamil A, Seema Y, Badruzzaman MK, Md. Nasrul $H$ Abdullah SA, Mubeen AA, Tauheed I, Ashok KA, Fakhrul I. Attenuation by Nardostachys jatamansi of 6-hydroxydopamineinduced parkinsonism in rats: behavioral, neurochemical, and immunohistochemical studies. Bharmacology Biochemistry and Behavior 2006;83(1):150-60

202. Warrier PK, Nambiar VPK, Ramankutty C. Indian Medicinal Plants: A Compendium of 500 Species. Orient Longman, Madras, India (1996).

203. Mishra LC, Singh BB, Dagenais S. Scientific basis for the therapeutic use of Withania somnifera (ashwagandha): a review. Altern Med Rev 5 2000;5(4):334-46.

204. Yousuf SK, Majeed R, Ahmad M, Sangwan P, Purnima B, Saxsena AK, et al. Taneja, Ring A structural modified derivatives of withaferin $A$ and the evaluation of their cytotoxic potential. Steroids.
2011;76(10):1213-22

205. Mayola E, Gallerne C, Esposti DD, Martel C, Pervaiz S, Larue L, et al. Withaferin A induces apoptosis in humanmelanoma cells through generation of reactive oxygen species and downregulation of Bcl-2, apoptosis. 2011;16(10):1014-27.

206. Thaiparambil JT, Bender $L$, Ganesh $T$, Kline E, Patel P, Liu Y, Tighiouart M, Vertino PM, Harvey RD, Garcia A, Marcus Al. Withaferin A inhibits breast cancer invasion and metastasis at sub-cytotoxic doses by inducing vimentin disassembly and serine 56 phosphorylation. Int J Cancer. 2011;129(11):2744-55.

207. Stan SD, Zeng Y, Singh SV. Ayurvedic medicine constituent withaferin A causes G2 and M phase cell cycle arrest in human breast cancer cells. Nutr Cancer. 2008;60(s1):51-60.

208. Mohan R, Hammers HJ, Bargagna-Mohan $P$, Zhan XH, Herbstritt CJ, Ruiz $A$ Zhang $L$, Hanson AD, Conner BP, Rougas J, Pribluda VS. Withaferin A is a potent inhibitor of angiogenesis, Angiogenesis. 2004;7(2):115-22

209. Sharanbasappa D, Shivsharan BD, Ravichandra V, Badamaranahalli SS, Chabbanahalli SC. Withania somnifera (Ashwagandha) in neurobehavioural disorders induced by brain oxidative stress in rodents: a systematic review and meta-analysis. Journal of Pharmacy and Pharmacology. 2015;67:879-99.

210. Kushwaha S, Soni VK, Singh PK, Bano N, Kumar A, Sangwan RS, S. Misra-Bhattacharya, Withania somnifera chemotypes NMITLI 101R, NMITLI 118R, MITL 128R and Withaferin A protect Mastomys coucha from Brugia malayi infection Parasite Immunol. (2011), http://dx.doi.org/10.1111/j.1365-3024.2011.01352.x.

211. Sudhir S, Budhiraja RD. Comparison of the protective effect of Withaferin-'A' and hydrocortisone against CCL4 induced hepatotoxicity in rats. Indian J Physiol Pharmacol. 1992;36(2):127-129.

212. Kuboyama T, Tohda C, Komatsu K Neuritic regeneration and synaptic reconstruction induced by withanolide A. Br J Pharmacol. 2005;144(7):961-71.

213. Tohda C, KuboyamaT, Komatsu K, Search for natural products related to regeneration of the neuronal network, Neurosignals. 2005;14(1-2):34-45.

214. Bhattacharya SK, Bhattacharya A, Sairam K, Ghoshal S. Anxiolytic-antidepressant activity of Withania somnifera glycowithanolides: an experimental study. Phytomedicine. 2000;7(6):463-9

215. Sehgal N, Gupta A, Valli RK, Joshi SD, Mills JT, Hamel E, Khanna P, et al. Withania somnifera reverses Alzheimer's disease pathology by enhancing low-density lipoprotein receptor-related protein in liver. Proc Natl Acad Sci S A. 2012;28;109(9):3510-5

216. Jaiprakasam B, Padmanabhan K, Nair MG. Withanamides in Withania somnifera fruit protects PC-12 cells from beta-amyloid responsible for Alzheimer's disease. Phytother Res. 2010:24(6):859-63.

217. Kumar S, Harris RJ, Seal CJ, Okello EJ: An aqueous extract of Withania somnifera root inhibits amyloid beta fibril formation in vitro. Phytother Res. 2012,26:113-7.

218. Singh RH, Narsimhamurthy K, Singh G. Neuronutrient impact of Ayurvedic Rasayana therapy in brain aging. Biogerontology. 2008;9(6):369-74

219. Molloy SA, Rowan EN, O'Brien JT, McKeith IG, Wesnes K, Burn DJ. Effect of levodopa on cognitive function in Parkinson's disease with and without dementia and dementia with Lewy bodies. J Neurol Neurosurg Psychiatr. 2006;77:1323-8.

220. Kumar KVA, Srinivasan KK, Shanbhag T, Rao SG. Aphrodisiac activity of the seeds of Mucuna pruriens. Indian Drug. 1994;31:321-7.

221. Manyam BV, Dhanasekaran M, Hare TA. Neuroprotective effects of the antiparkinson drug. Mucuna Pruriens Phytother Res. 2004;18(9):706-712

222. Sharma ML, Chandhoke N, Ray Ghatak BJ, Jamwal KS, Gupta OP, Singh GB. Pharmacological screening of Indian medicinal plants. Indian J Exp Biol. 1978;16:228-35

223. Misra L, Wagner $H$. Extraction of bioactive principle from Mucuna pruriens seeds. Indian J Biochem Biophys. 2007;44(1):56-60.

224. Kamla KS, Abbas AM, Mohammad KA, Shyam PJ, Satya NS, Sarvada CT. Mucuna pruriens Reduces Stress and Improves the Quality of Semen in Infertile Men. eCAM. 2010;7(1)137-144.

225. Satyndra KY, Jay P, Shikha C, Surya PS. Mucuna pruriens seed extract reduces oxidative stress in nigrostriatal tissue and improves neurobehavioral activity in paraquatinduced Parkinsonian mouse model. Neurochemistry International. 2013;62(8):1039-47.

226. $\mathrm{RH}$ singh. Ayurvediya manas vijnan. Varanasi. Chaukhamba publications. 1986.

227. Kulkarni R, Girish KJ, Kumar A. Nootropic herbs (Medhya Rasayana) in Ayurveda: An update. Phcog Rev [serial online] [cited 2012 Oct 17 ] 2012;6(12):147-53.

228. Bhava pN, Bhavaprakasha, Hindi commentary, Chunekar KC, Guduchyadi Varga (281), pg.461, Chaukhambha Bharati Academy, Varanasi (2002)

229. Bhava pN, Bhavaprakasha, Hindi commentary, Chunekar KC, Guduchyadi Varga (189), pg.393, Chaukhambha Bharati Academy, Varanasi (2002).

230. Bhava pN, Bhavaprakasha, Hindi commentary, Chunekar KC, Haritakyadi Varga (31), pg.6, Chaukhambha Bharati Academy, Varanasi (2002). 


\section{SUMMARY}

- Rasayana herbs of Ayurveda namely Amalaki (Emblica officinalis), Hareetaki (Terminalia chebula), Haridra (Curcuma longa), Manduka parni(Centella asiatica), Aindri (Bacopa monniera), Yastimadhu (Glycirrhiza glabra), Guduchi (Tinospora cordifolia), Shankhapushpi (Convolvulus pleuricaulis), Vacha (Acorus calamus), Jyotishmati (Celastrus panniculata), Kushmanda (Benincasa hispida), Jatamamsi (Nardostachys jatamamsı) and Ashvagandha (Withania somnifera) are beneficial in prevention and management of age related cognitive decline. Factors that aid in anti-dementia and neuro protection are acetylcholine estarase inhibition, NMDA antagonism, Dopaminergic activity, removal of amyloidal plaques, inhibition of Tau aggregation, Folic acid, glutamic acid, Vitamin B etc apart from antioxidant activity.

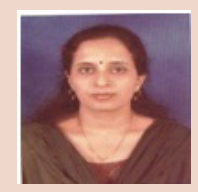

\section{ABOUT AUTHORS}

Reena Kulkarni: Is a practicing Ayurveda Pediatrician who has obtained Post Doctoral degree from Dr Sarvepalli Radhakrishnan Rajasthan Ayurveda University, Jodhpur in 2015 and is Masters in Clinical child development from university of Kerala, Thiruvananthapuram. She positioned as Associate professor at Sri Dharmasthala Manjunatheshwara College of Ayurveda \& Hospital, Hassan, India. Dr Kulkarni is an expert in Ayurveda management of various childhood respiratory, allergic and developmental disorders. At present she is working on Medhya Rasayana their therapeutic applications in preventive pediatrics.

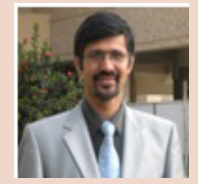

Suhas Kumar Shetty: Obtained his Ph. D. degree in Ayurveda from Rajiv Gandhi university of health Sciences Karnataka, Bangalore in 2016. He is positioned as Professor at Sri Dharmasthala Manjunatheshwara College of Ayurveda \& Hospital, Hassan, India. Dr. Shetty is working on various aspects of Ayurvedic management of psychiatric disorders and engaged in finding preventive as well as therapeutic solutions from Ayurvedic principles. $\mathrm{He}$ is also an expert in Medical Statistics in the field of Ayurveda.

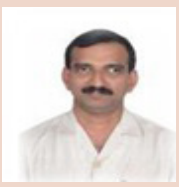

Prasanna Narasimha Rao: Obtained his Post Doctoral degree in 1994 from the prestigious Banaras Hindu University, Varanasi. He is currently positioned as Principal, Sri Dharmasthala Manjunatheshwara College of Ayurveda and Hospital, Hassan, India. Dr Rao is an expert in Shalya Tantra (Surgery) has a vast experience of 21 years in Administration as well as Ayurveda practice. He has visited many overseas universities and engaged in various teaching and learning programmes and guiding Graduate, Post graduate and Doctoral scholars. He is also an active advisory board member to many Government and Non government organizations in the field of Ayurveda. 